\title{
Vanadium toxicity in the thymic development
}

\author{
Wei Cui ${ }^{1, *}$, Hongrui Guo ${ }^{1, *}$ and Hengmin Cui ${ }^{1,2}$ \\ ${ }^{1}$ Key Laboratory of Animal Diseases and Environmental Hazards of Sichuan Province, Sichuan Agricultural University, Ya'an, \\ China \\ ${ }^{2}$ College of Veterinary Medicine, Sichuan Agricultural University, Ya'an, China \\ * These authors have contributed equally to this work \\ Correspondence to: Hengmin Cui, email: cuihengmin2008@sina.com
}

Keywords: vanadium, relative weight, cell cycle, apoptosis, protein expression, Immunology and Microbiology section, Immunity, Immune response

Received: July 15, 2015

Accepted: August 26, 2015

Published: September 22, 2015

This is an open-access article distributed under the terms of the Creative Commons Attribution License, which permits unrestricted use, distribution, and reproduction in any medium, provided the original author and source are credited.

\section{ABSTRACT}

The purpose of this study was to define the toxic effects of vanadium on thymic development in broilers fed on diets supplemented with 0, 5, 15, 30, 45 and 60 $\mathrm{mg} / \mathrm{kg}$ of vanadium for 42 days. We examined the changes of relative weight, cell cycle phase, apoptotic cells, and protein expression of $\mathrm{Bcl}-2, \mathrm{Bax}$, and caspase-3 in the thymus by the methods of flow cytometry, TUNEL (terminal-deoxynucleotidyl transferase mediated nick end labeling) and immunohistochemistry. The results showed that dietary high vanadium $(30 \mathrm{mg} / \mathrm{kg}, 45 \mathrm{mg} / \mathrm{kg}$ and $60 \mathrm{mg} / \mathrm{kg})$ caused the toxic effects on thymic development, which was characterized by decreasing relative weight, increasing $G_{0} / G_{1}$ phase (a prolonged nondividing state), reducing $S$ phase (DNA replication) and proliferating index (PI), and increasing percentages of apoptotic thymocytes. Concurrently, the protein expression levels of Bax and caspase-3 were increased, and protein expression levels of $\mathrm{Bcl}-2$ were decreased. The thymic development suppression caused by dietary high vanadium further leads to inhibitive effects on $\mathrm{T}$ lymphocyte maturity and activity, and cellular immune function. The above-mentioned results provide new evidences for further understanding the vanadium immunotoxicity. In contrast, dietary $5 \mathrm{mg} / \mathrm{kg}$ vanadium promoted the thymic development by increasing relative weight, decreasing $G_{0} / G_{1}$ phase, increasing $S$ phase and PI, and reducing percentages of apoptotic thymocytes when compared to the control group and high vanadium groups.

\section{INTRODUCTION}

Vanadium, as a transition element or an important mineral distributed on earth, is used widely in the chemical industry and is contained in several foods, water particulates in air, fuel oils, and coal [1-4]. It is also considered to be a nutritionally essential trace element for animal species [5-8]. At present, vanadium or vanadium compounds have been known as new promising drugs for lowering blood glucose in diabetes due to their insulinmimetic actions and ability to counteract insulin resistance $[2,4,6,9-20]$. Also, they have been used in clinical practice to protect against tumor or cancer as a potent anticarcinogenic agent or antitumor drugs [4, 21-23]. At the same time, there have been a lots of reports focused on the toxic actions or side effects of vanadium and vanadium compounds, which constitutes another important area of research on vanadium.

The toxicity of vanadium compounds usually increases as the valence increases. The pentavalent compounds are the most toxic [24]. In vivo study in the laying hen has shown that dietary vanadium reduces body weight, feed consumption, egg production, egg weight and shell quality [25]. Oxidative stress or damage, reproductive toxicity (teratogenicity and embryotoxicity), organ and tissue injury, neurobehavioral injury or neurotoxicity, Mitochondrial dysfunction or injury, genotoxicity, cytotoxicity and blood toxicity induced by vanadium or vanadium compounds is well documented: in vivo and in vitro of both man and animals $[4,12,18$, 
24, 26-52]. Sumanta et al. (2015) have reviewed that vanadium or vanadium compounds cause toxic effects including blood toxicity, abnormalities in development and reproduction (teratogenicity and embryotoxicity), neurobehavioral injury, morphological and functional lesions in liver, kidneys, bones, spleen and leukocytes, and inflammatory responses including rhinitis, pharyngitis, chronic productive cough, tracheobronchitis and bronchopneumonia [53]. Vanadium immunotoxicity is also appeared in the rat and rabbit [54]. Our previous studies have shown that dietary vanadium in $30 \mathrm{mg} / \mathrm{kg}$ and over causes lesions, oxidative damage, immunotoxicity, cytokine reduction, apoptosis, cell cycle arrest and microbiota alteration in the cecal tonsil, spleen, bursa of Fabricius, kidney, liver, intestine and serum [55-72]. Michael et al. (1987) have concluded that animals during periods of rapid growth are susceptible to vanadium toxicity, and increased lipid peroxidation may be one factor [73].

The thymus is the central lymphoid organ, and it forms and grows immediately after birth in response to postnatal antigenic stimulation and the demand for large numbers of mature $\mathrm{T}$ cells [74]. The number of mature $\mathrm{T}$ cells decides the biological function of the cells and is correlated to the cellular immune function of the body [75]. However, very limited data focus on the toxic effects of vanadium on thymic development in human beings and animals at present.

The aim of present research was to define the toxic effects of vanadium on thymic development by observing the changes of relative weight, cell cycle phase, percentages of apoptotic thymocytes and protein expression of apoptotic proteins (bcl-2, bax, and caspase-3) using the methods of flow cytometry, TUNEL (terminal-deoxynucleotidyl transferase mediated nick end labeling) and immunohistochemistry.

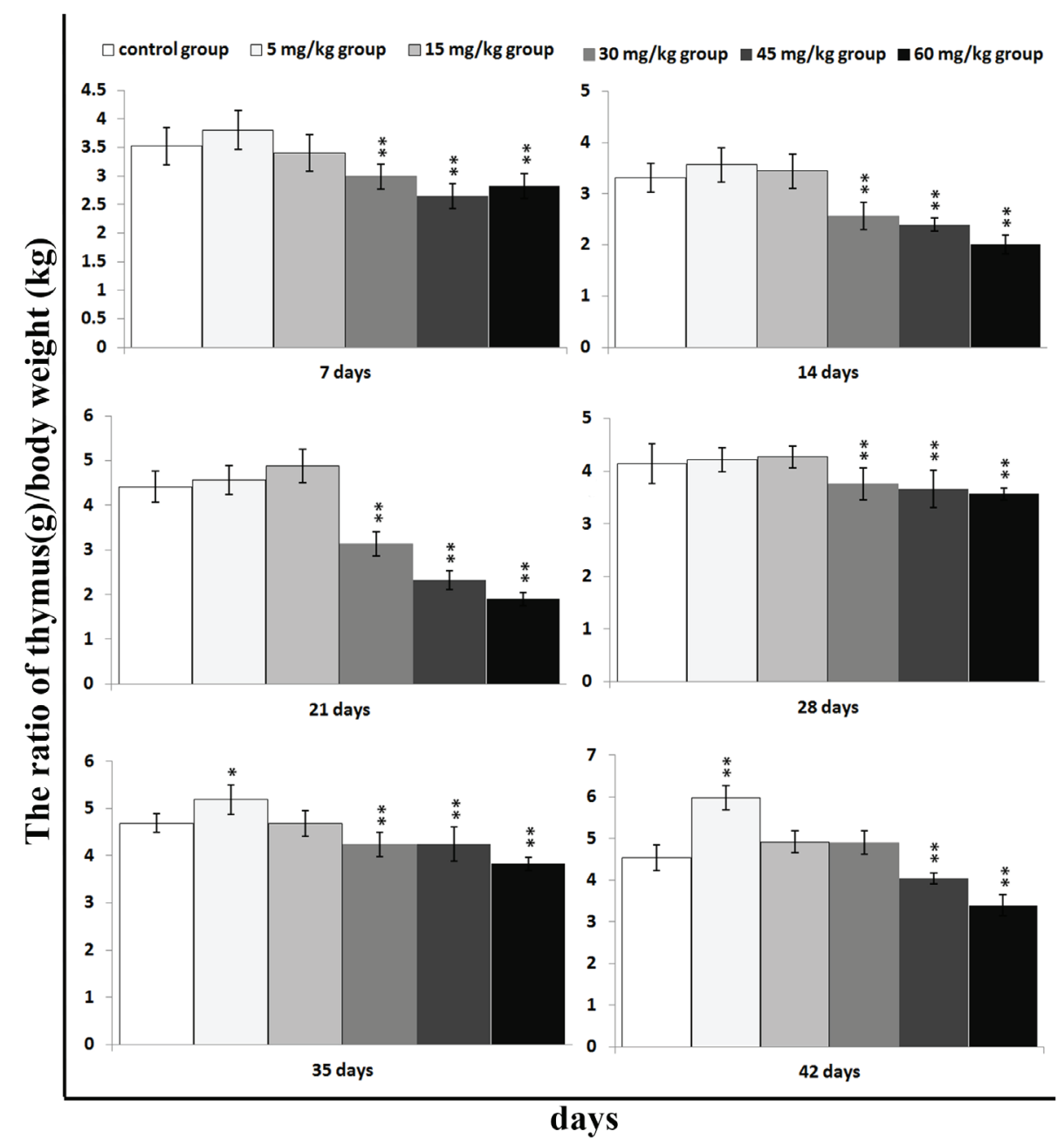

Figure 1: Changes of relative weight [thymus $(\mathrm{g}) / \mathrm{body}$ weight $(\mathrm{kg})]$ in the thymus Data are the means \pm standard deviation $(\mathrm{n}=5) * p<0.05$, compared with the control group ${ }^{* *} p<0.01$, compared with the control group. 


\section{RESULTS}

\section{Clinical observation}

Broilers grew much faster in $5 \mathrm{mg} / \mathrm{kg}$ group and much slower in 30,45 and $60 \mathrm{mg} / \mathrm{kg}$ groups than in control group. Broilers in 45 and $60 \mathrm{mg} / \mathrm{kg}$ groups showed decreased feed intake and depression. Loss of body weight of $35.31 \%, 44.03 \%$, and $68.05 \%$ was seen in 30,45 and 60 $\mathrm{mg} / \mathrm{kg}$ groups, respectively, at the end of the experiment when compared with that in the control group.

\section{Change of thymic relative weight}

The thymic relative weight was significantly lower $(P<0.01)$ in the $30 \mathrm{mg} / \mathrm{kg}, 45 \mathrm{mg} / \mathrm{kg}$ and $60 \mathrm{mg} / \mathrm{kg}$ groups than those in the control group from 7 to 42 days of age, except $30 \mathrm{mg} / \mathrm{kg}$ group at 42 days of age. At the same time, the thymic relative weight was significantly increased $(P<$ 0.05 or $P<0.01$ ) in the $5 \mathrm{mg} / \mathrm{kg}$ group at 35 and 42 days of age when compared with those in the control group. The results are shown in Figure 1.

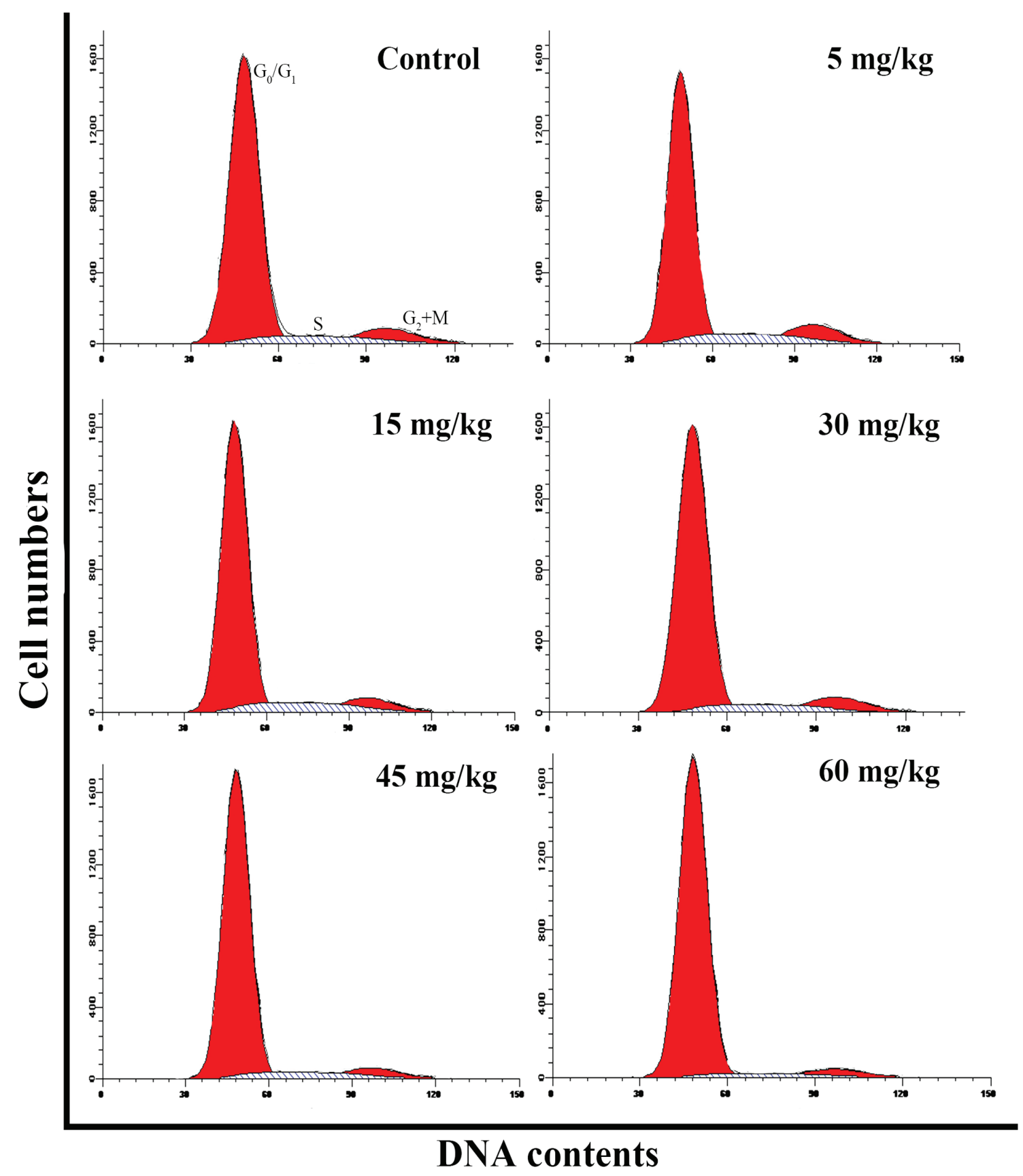

Figure 2: Changes of cell cycle in the thymus by flow cytometry at 42 days of age. 


\section{Changes of cell cycle in the thymus}

The percentages of $\mathrm{G}_{0} / \mathrm{G}_{1}$ phase (a prolonged nondividing state) were significantly decreased $(P<0.05$ or $P<0.01)$ in the $5 \mathrm{mg} / \mathrm{kg}$ group from 14 to 42 days of age. Moreover, the percentages of $\mathrm{G}_{0} / \mathrm{G}_{1}$ phase were markedly higher $(P<0.05$ or $P<0.01)$ in 45 and $60 \mathrm{mg} /$ $\mathrm{kg}$ groups than those in the control group from 14 to 42 days of age.

The percentages of $\mathrm{G}_{2}+\mathrm{M}$ phase were markedly increased $(P<0.05$ or $P<0.01)$ in $5 \mathrm{mg} / \mathrm{kg}$ when compared with those in the control group. However, the percentages of the $\mathrm{G}_{2}+\mathrm{M}$ phase were lower $(P<0.05$ or $P$ $<0.01)$ in the $45 \mathrm{mg} / \mathrm{kg}$ and $60 \mathrm{mg} / \mathrm{kg}$ groups than those in the control group from 14 to 42 days of age.

The percentages of S phase (DNA replication) were significantly decreased $(P<0.01)$ in the $30 \mathrm{mg} / \mathrm{kg}, 45 \mathrm{mg} /$ $\mathrm{kg}$ and $60 \mathrm{mg} / \mathrm{kg}$ groups from 14 to 42 days of age, and were increased $(P<0.05)$ in the $5 \mathrm{mg} / \mathrm{kg}$ group at 14 days of age when compared with those in the control group.

The proliferating index (PI) value was markedly increased $(P<0.05$ or $P<0.01)$ in the $5 \mathrm{mg} / \mathrm{kg}$ from 14 to 42 days of age. Meanwhile, the PI was markedly lower $(P$ $<0.05$ or $P<0.01)$ in the $45 \mathrm{mg} / \mathrm{kg}$ and $60 \mathrm{mg} / \mathrm{kg}$ groups from 14 to 42 days of age and in the $30 \mathrm{mg} / \mathrm{kg}$ group at 42 days of age than that in the control group.

The abovementioned results are shown in Figures $2,3,4,5$ and 6 .

\section{$\square$ control group $\square 5 \mathrm{mg} / \mathrm{kg}$ group $\square 15 \mathrm{mg} / \mathrm{kg}$ group $\square 30 \mathrm{mg} / \mathrm{kg}$ group $\square 45 \mathrm{mg} / \mathrm{kg}$ group $\square 60 \mathrm{mg} / \mathrm{kg}$ group}

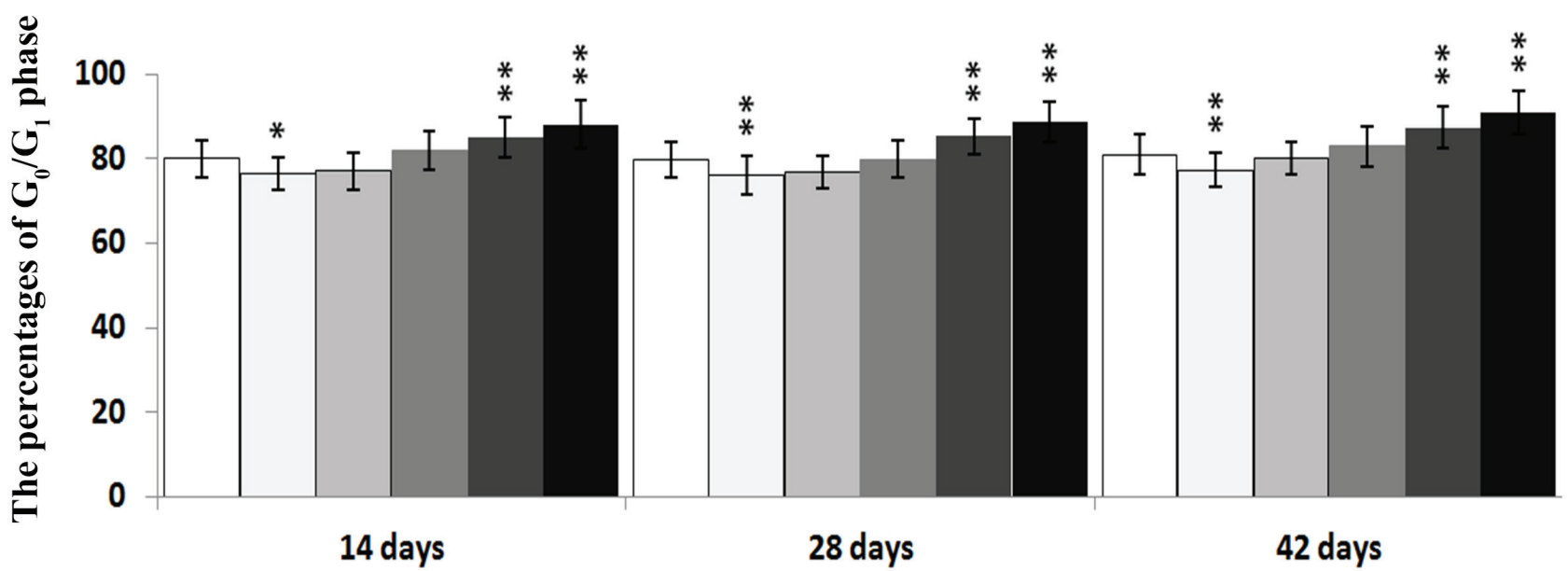

Figure 3: Changes of the percentages of G0/G1 phase in the thymus Data are the means \pm standard deviation $(\mathrm{n}=5){ }^{*} p<0.05$, compared with the control group ${ }^{* *} p<0.01$, compared with the control group.

\section{$\square$ control group $\square 5 \mathrm{mg} / \mathrm{kg}$ group $\square 15 \mathrm{mg} / \mathrm{kg}$ group $\square 30 \mathrm{mg} / \mathrm{kg}$ group $\square 45 \mathrm{mg} / \mathrm{kg}$ group $\square 60 \mathrm{mg} / \mathrm{kg}$ group}

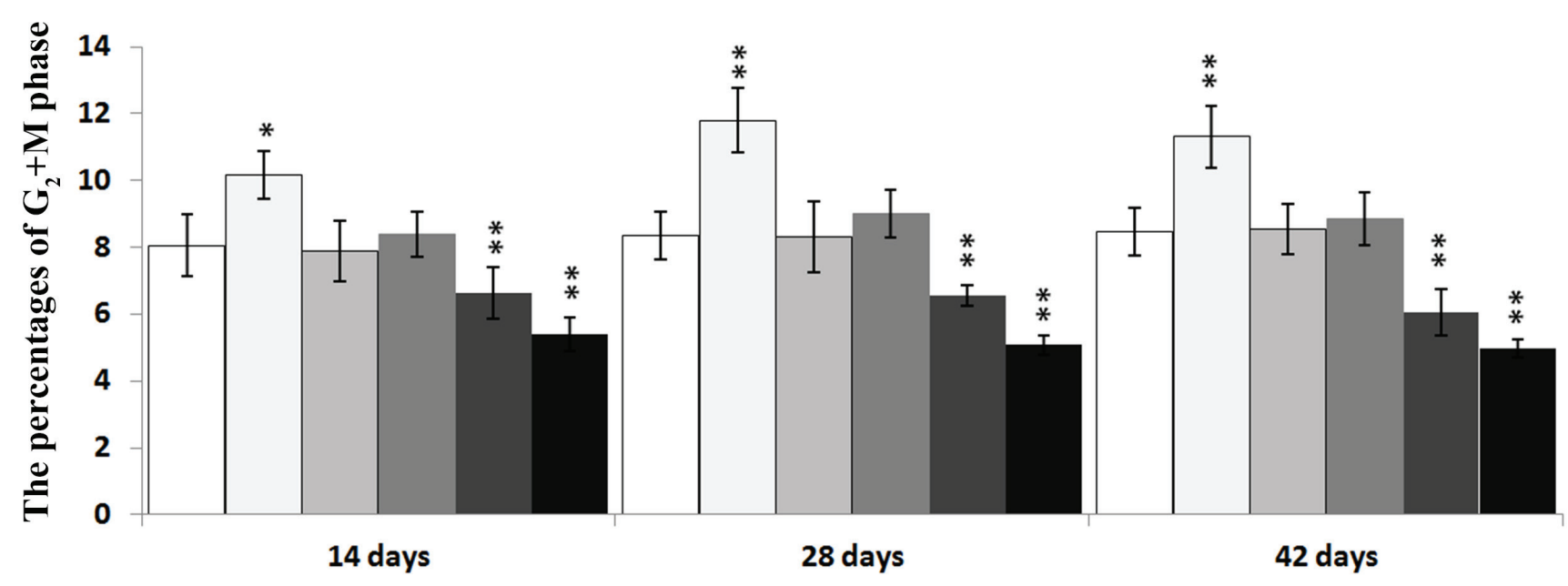

Figure 4: Changes of the percentages of $\mathbf{G 2}+\mathbf{M}$ phase in the thymus Data are the means \pm standard deviation $(\mathrm{n}=5){ }^{*} p<0.05$, compared with the control group $* * p<0.01$, compared with the control group. 


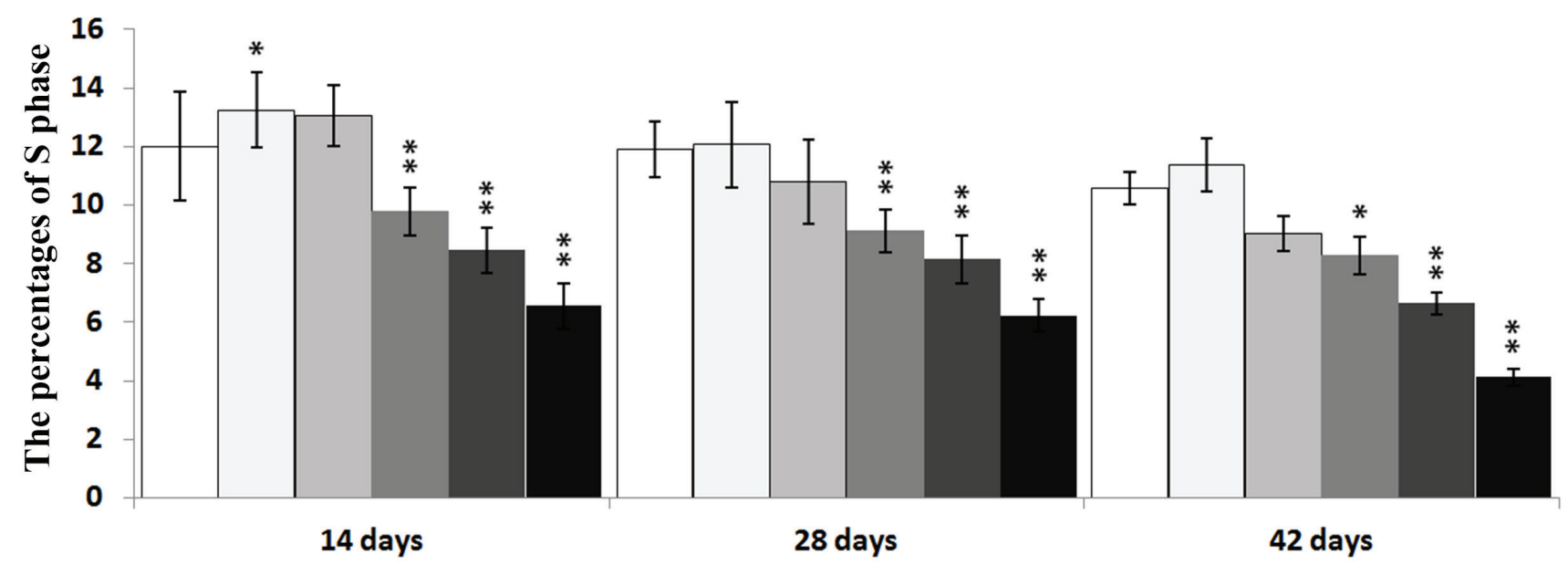

Figure 5: Changes of the percentages of $\mathbf{S}$ phase in the thymus Data are the means \pm standard deviation $(\mathrm{n}=5) * p<0.05$, compared with the control group $* * p<0.01$, compared with the control group.

\section{$\square$ control group $\square 5 \mathrm{mg} / \mathrm{kg}$ group $\square 15 \mathrm{mg} / \mathrm{kg}$ group $\square 30 \mathrm{mg} / \mathrm{kg}$ group $\square 45 \mathrm{mg} / \mathrm{kg}$ group $\square 60 \mathrm{mg} / \mathrm{kg}$ group}

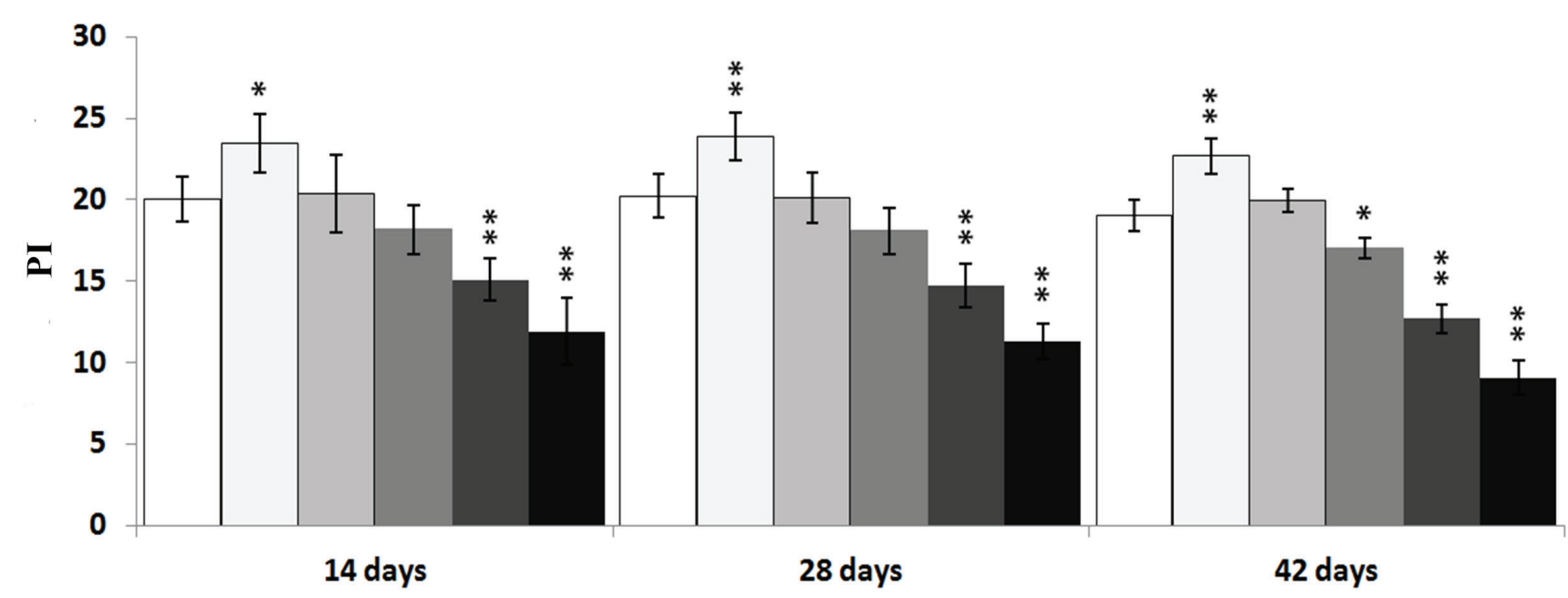

Figure 6: Changes of thymocyte PI (proliferating index) $\mathrm{PI}=(\mathrm{S}+(\mathrm{G} 2+\mathrm{M})) /((\mathrm{G} 0 / \mathrm{G} 1)+\mathrm{S}+(\mathrm{G} 2+\mathrm{M}))$ Data are the means \pm standard deviation $(\mathrm{n}=5) * p<0.05$, compared with the control group $* * p<0.01$, compared with the control group.

\section{Changes of apoptosis in the thymus}

Flow cytometry method The results in Figures 7 and 8 showed that the percentages of apoptotic cells in the thymus were increased as dietary vanadium level increased. The percentages of apoptotic thymocytes were significantly higher $(P<0.01)$ in the $30 \mathrm{mg} / \mathrm{kg}, 45 \mathrm{mg} / \mathrm{kg}$ and $60 \mathrm{mg} / \mathrm{kg}$ groups than those in the control group.

TUNEL assay TUNEL assay showed apoptotic thymocytes with brown-stained nuclei. There were increased frequencies of apoptotic thymocytes in the 30 $\mathrm{mg} / \mathrm{kg}, 45 \mathrm{mg} / \mathrm{kg}$ and $60 \mathrm{mg} / \mathrm{kg}$ groups when compared with those in the control group, as shown in Figure 9.

\section{Changes of the Bcl-2, Bax and caspase-3 protein} expression in the thymus

Bax protein expression Changes of the Bax protein expression levels were no observed in the 5-mg/ $\mathrm{kg}$ group. The positive thymocytes containing Bax protein expression were increased in the $30 \mathrm{mg} / \mathrm{kg}, 45 \mathrm{mg} / \mathrm{kg}$ and $60 \mathrm{mg} / \mathrm{kg}$ groups when compared with those of the control group from 14 to 42 days of age. The results were shown in Figures 10 and 11.

Bcl-2 protein expression Changes of the $\mathrm{Bcl}-2$ protein expression levels were no observed in the $5-\mathrm{mg} / \mathrm{kg}$ group. The positive thymocytes containing Bcl-2 protein expression were lower in the $30 \mathrm{mg} / \mathrm{kg}, 45 \mathrm{mg} / \mathrm{kg}$ and 60 


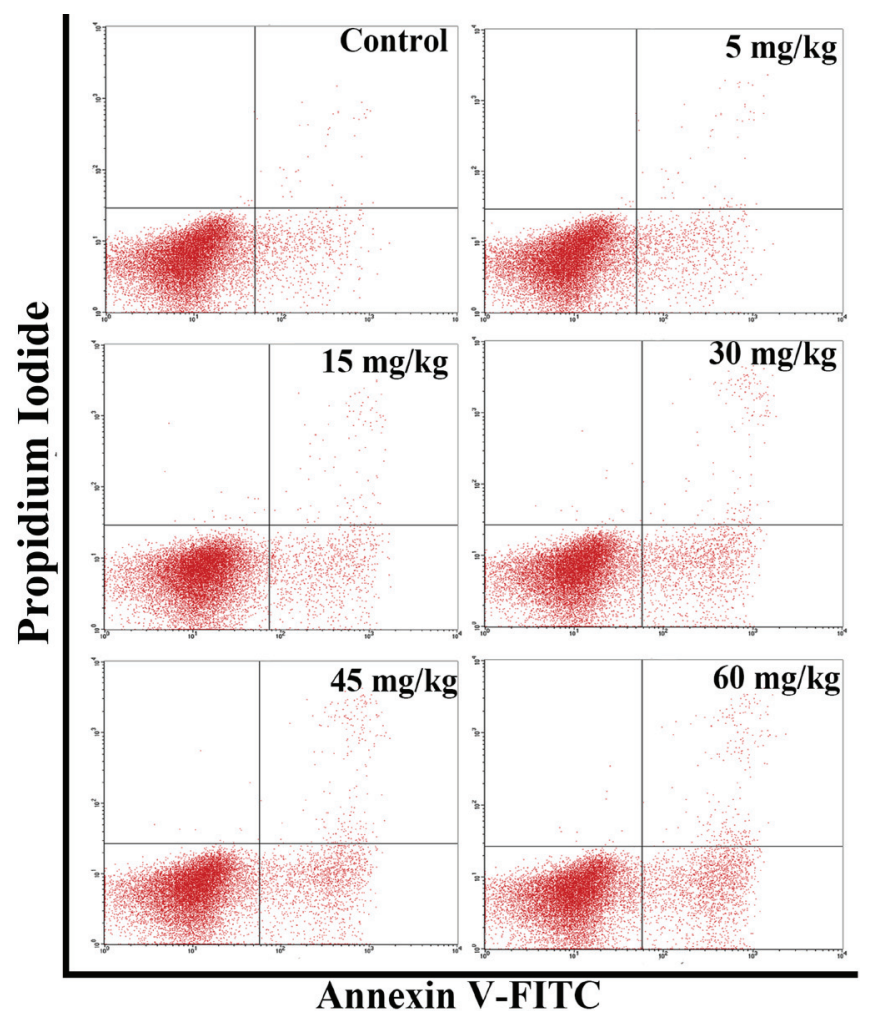

Figure 7: Changes of the apoptosis in the thymus by flow cytometry at 42 days of age.
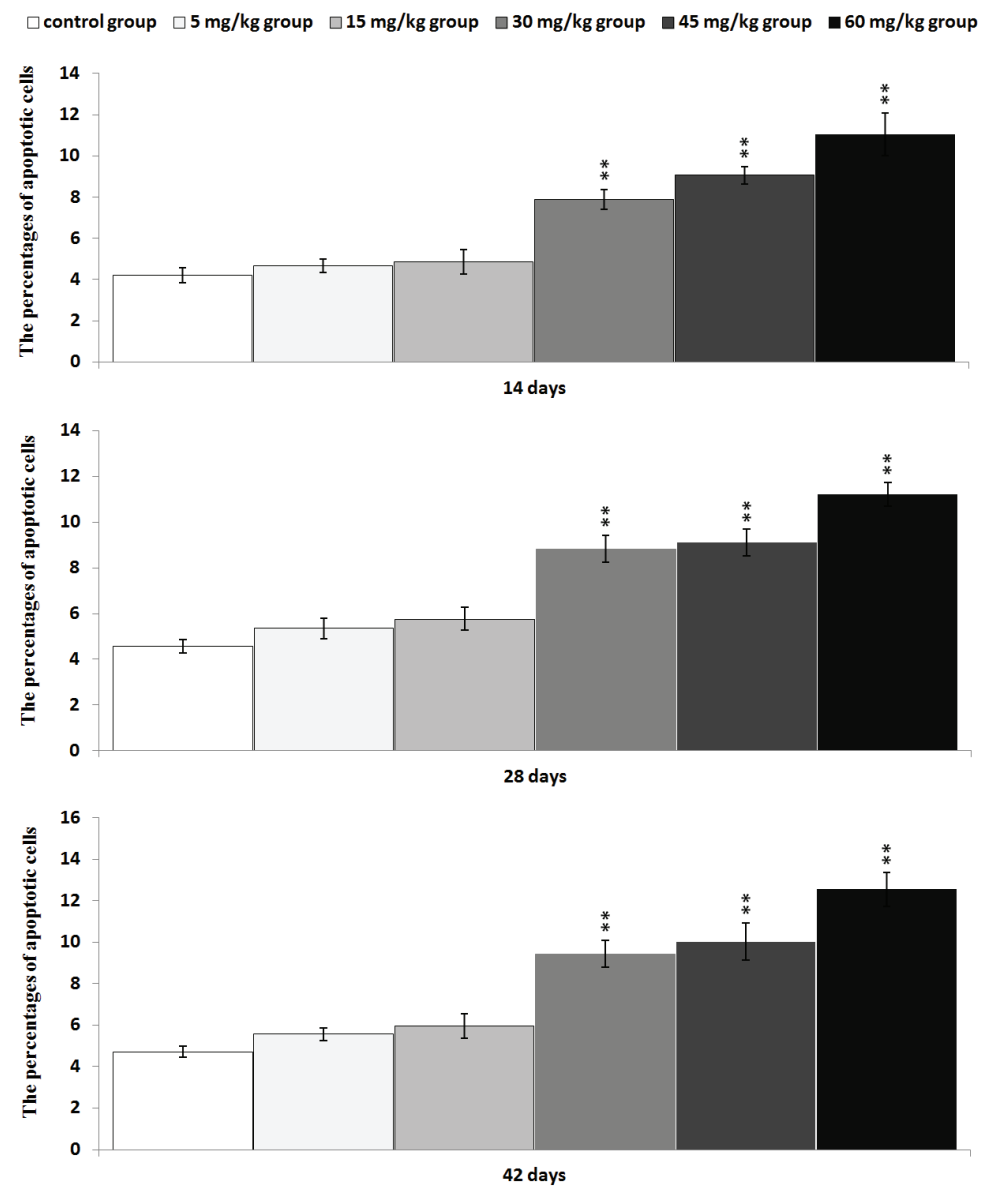

Figure 8: Changes of the percentages of apoptotic cells in the thymus by flow cytometry Data are the means \pm standard deviation $(\mathrm{n}=5){ }^{*} p<0.05$, compared with the control group ${ }^{* *} p<0.01$, compared with the control group. 

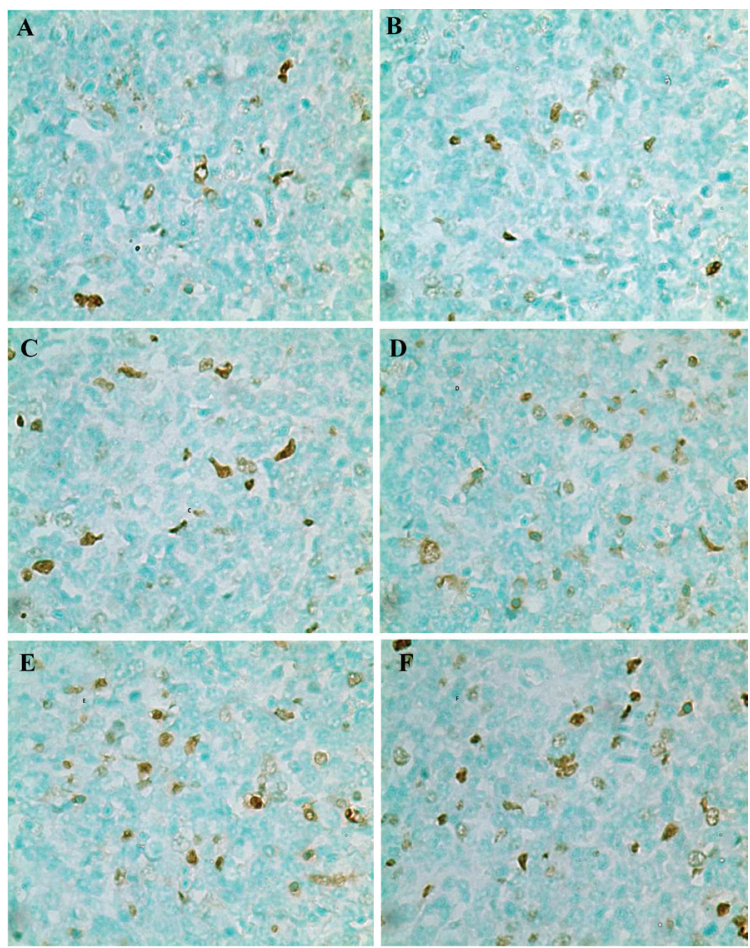

Figure 9: Apoptotic cells in the thymus by TUNEL at 42 days of age There are several apoptotic thymocytes (brown-stained nuclei) in control group (A). The numbers of apoptotic thymocytes are obviously increased in the $30 \mathrm{mg} / \mathrm{kg}$ group (D), $45 \mathrm{mg} / \mathrm{kg}$ group (E) and $60 \mathrm{mg} / \mathrm{kg}$ group $(\mathbf{F})$ at 42 days of age. TUNEL $\times 1000$.

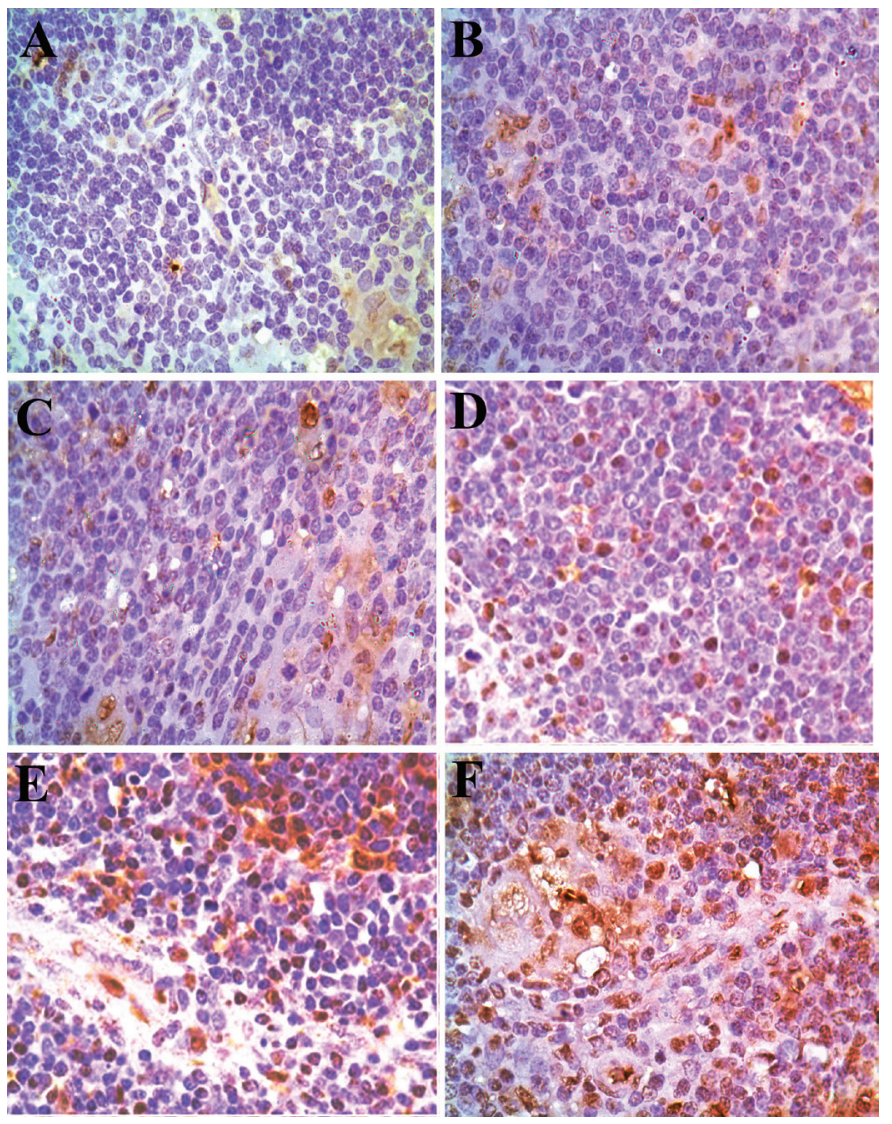

Figure 10: Changes of Bax protein expression in the thymus at 42 days of age There is less Bax protein expression (brownstained) in control group (A). The Bax protein expression is obviously increased in the $30 \mathrm{mg} / \mathrm{kg}$ group (D), $45 \mathrm{mg} / \mathrm{kg}$ group (E) and 60 $\mathrm{mg} / \mathrm{kg}$ group $(\mathbf{F})$ at 42 days of age. Immunohistochemistry $\times 1000$. 


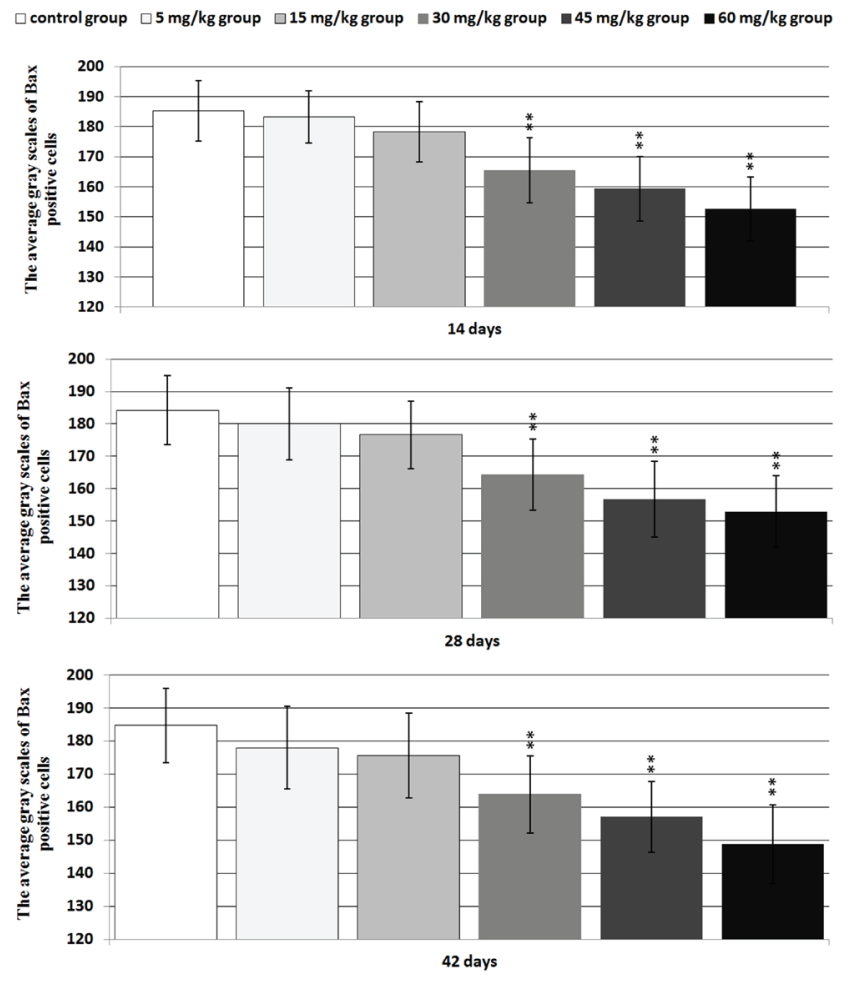

Figure 11: The average gray scales of positive cells containing Bax protein expression in the thymus. Immunoreactive intensity was expressed by average grayscale. Values $<160$ were considered high expression, 160-170 medium expression and 170-180 low expression. Data are the means \pm standard deviation $(\mathrm{n}=5 \times 5){ }^{*} p<0.05$, compared with the control group ${ }^{* *} p<0.01$, compared with the control group.

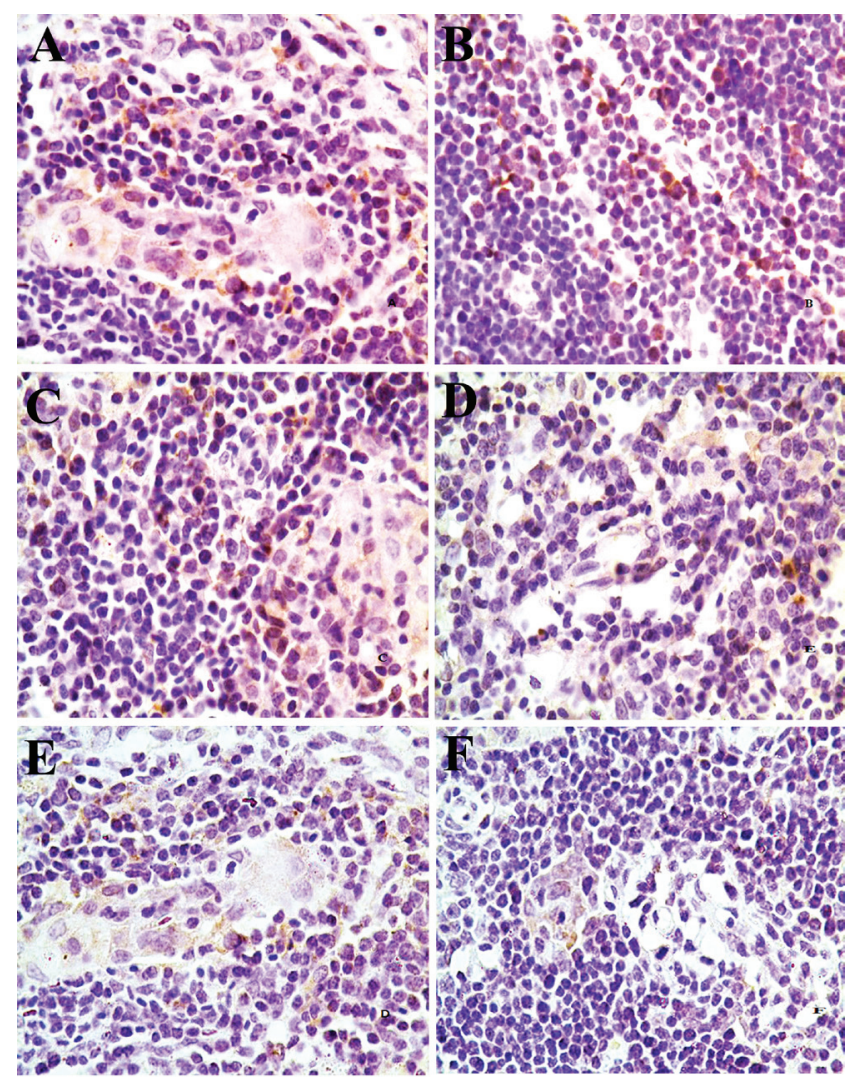

Figure 12: Changes of Bcl-2 protein expression in the thymus at 42 days of age There is abundant Bcl-2 protein expression (brown-stained) in control group (A). The Bcl-2 protein expression is obviously decreased in the $30 \mathrm{mg} / \mathrm{kg}$ group (D), $45 \mathrm{mg} / \mathrm{kg}$ group (E) and $60 \mathrm{mg} / \mathrm{kg}$ group $(\mathbf{F})$ at 42 days of age. Immunohistochemistry $\times 1000$. 
$\square$ controlgroup $\square 5 \mathrm{mg} / \mathrm{kg}$ group $\square 15 \mathrm{mg} / \mathrm{kg}$ group $=30 \mathrm{mg} / \mathrm{kg}$ group $\square 45 \mathrm{mg} / \mathrm{kg}$ group $\square 60 \mathrm{mg} / \mathrm{kg}$ group

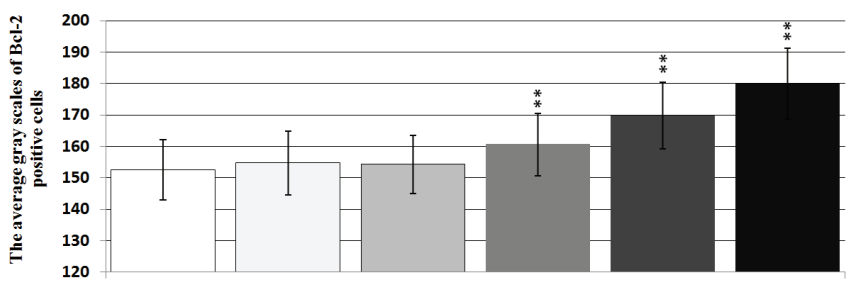

14 days
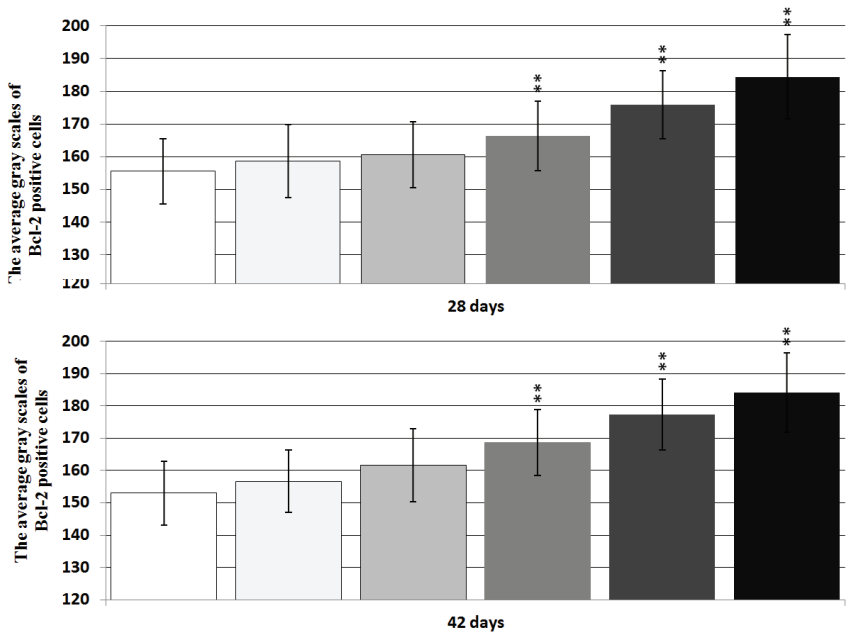

Figure 13: The average gray scales of positive cells containing Bcl-2 protein expression in the thymus. Immunoreactive intensity was expressed by average grayscale. Values $<160$ were considered high expression, 160-170 medium expression and 170-180 low expression. Data are the means \pm standard deviation $(\mathrm{n}=5 \times 5){ }^{*} p<0.05$, compared with the control group $* * p<0.01$, compared with the control group.

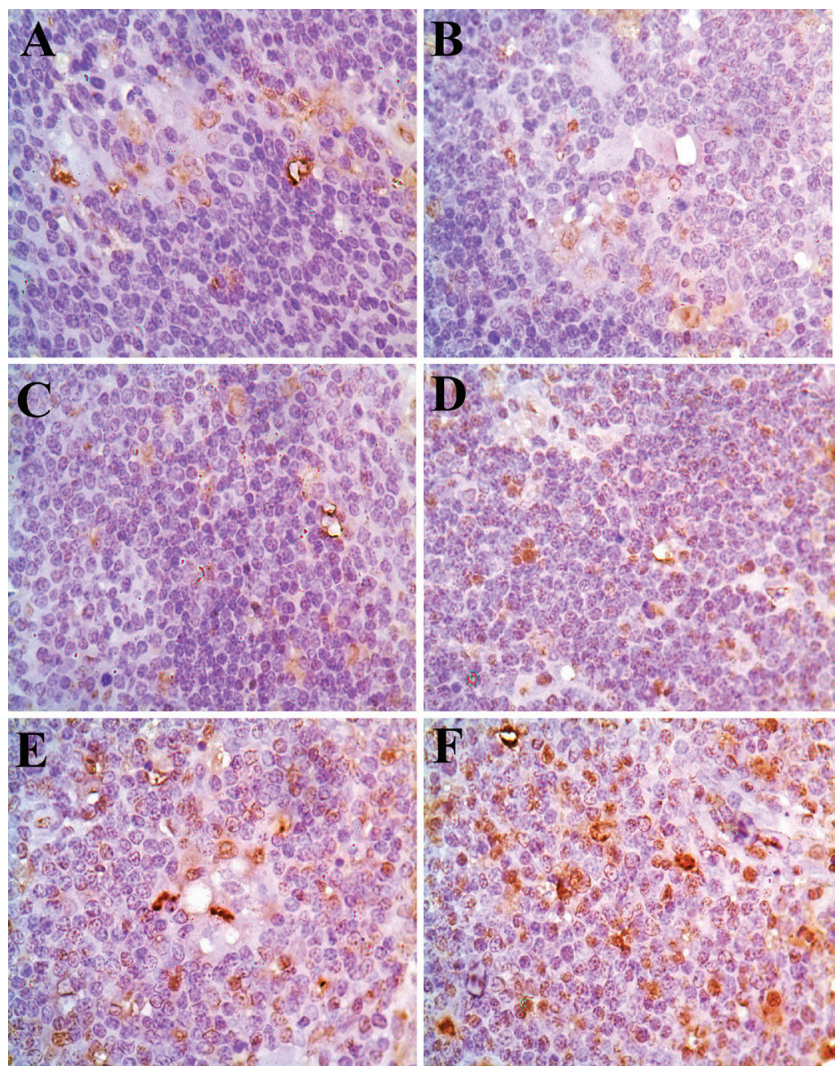

Figure 14: Changes of Caspase 3 protein expression in the thymus at 42 days of age There is less Caspase 3 protein expression (brown-stained) in control group (A). The Caspase 3 protein expression is obviously increased in the $30 \mathrm{mg} / \mathrm{kg}$ group (D), 45 $\mathrm{mg} / \mathrm{kg}$ group (E) and $60 \mathrm{mg} / \mathrm{kg}$ group (F) at 42 days of age. Immunohistochemistry $\times 1000$. 
$\square$ controlgroup $\square 5 \mathrm{mg} / \mathrm{kg}$ group $\square 15 \mathrm{mg} / \mathrm{kg}$ group $\square 30 \mathrm{mg} / \mathrm{kg}$ group $\square 45 \mathrm{mg} / \mathrm{kg}$ group $\square 60 \mathrm{mg} / \mathrm{kg}$ group
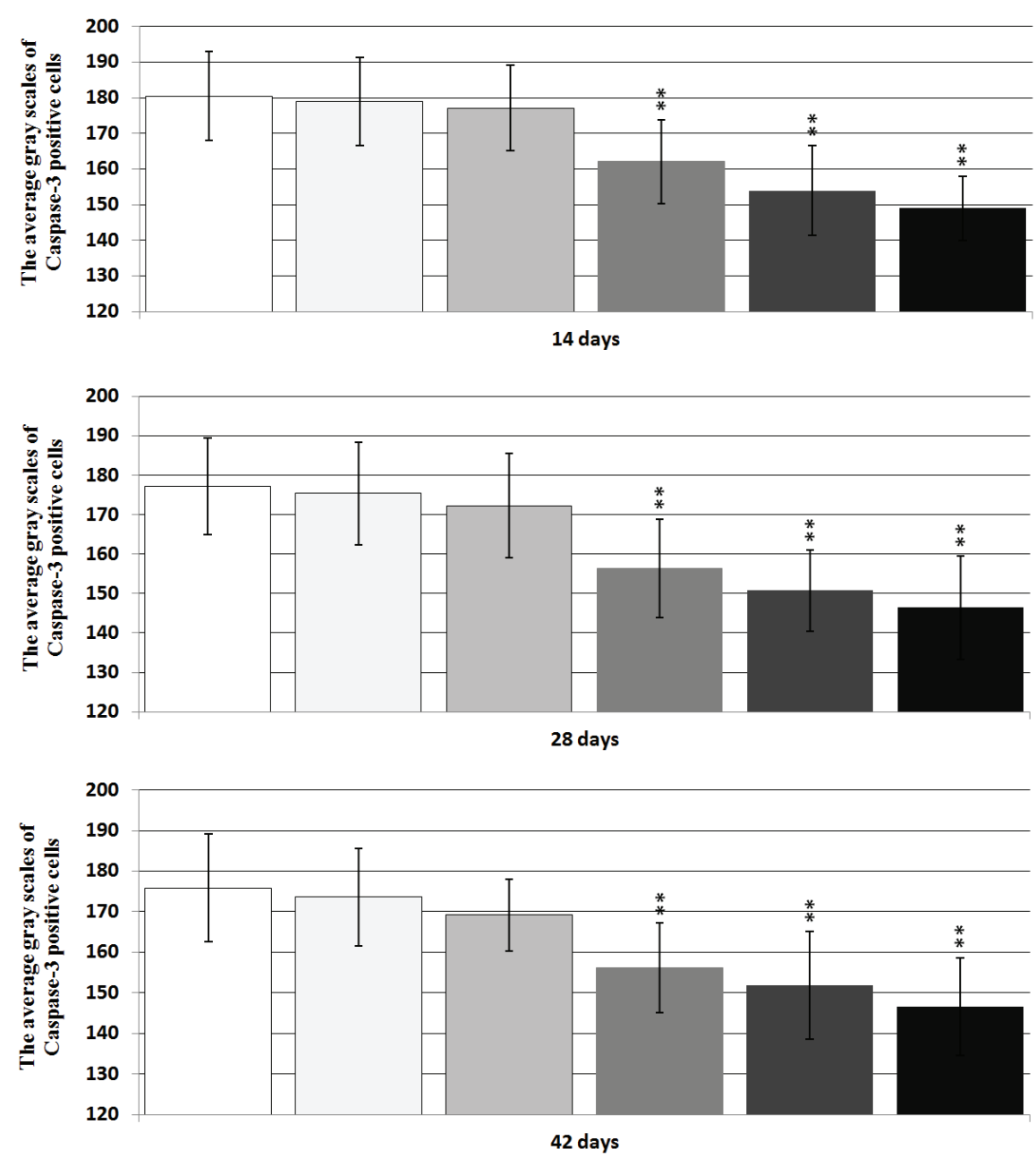

Figure 15: The average gray scales of positive cells containing caspase-3 protein expression in the thymus. Immunoreactive intensity was expressed by average grayscale. Values $<160$ were considered high expression, 160-170 medium expression and 170-180 low expression. Data are the means \pm standard deviation $(\mathrm{n}=5 \times 5){ }^{*} p<0.05$, compared with the control group ${ }^{* *} p<0.01$, compared with the control group.

\section{$\square$ control group $\square 5 \mathrm{mg} / \mathrm{kg}$ group $\square 15 \mathrm{mg} / \mathrm{kg}$ group $\square 30 \mathrm{mg} / \mathrm{kg}$ group $\square 45 \mathrm{mg} / \mathrm{kg}$ group $\square 60 \mathrm{mg} / \mathrm{kg}$ group}

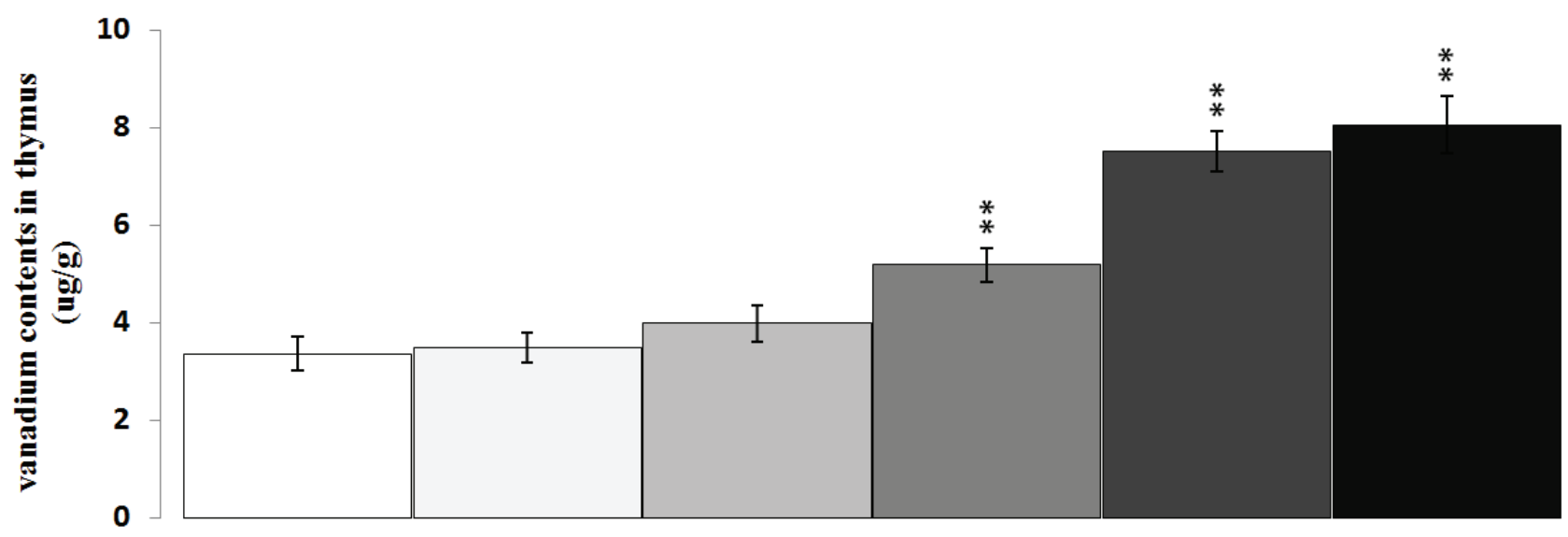

Figure 16: Changes of vanadium contents in the thymus at 42 days Data are the means \pm standard deviation $(\mathrm{n}=5) * p<0.05$, compared with the control group $* * p<0.01$, compared with the control group. 


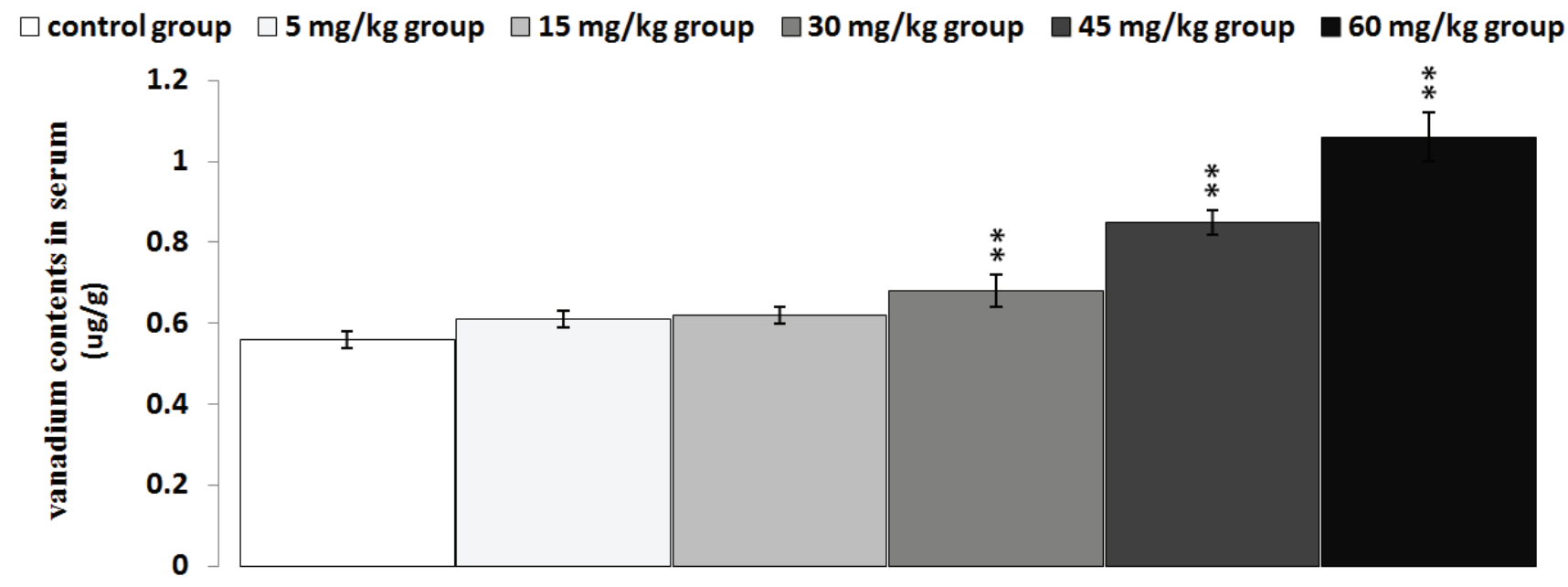

Figure 17: Changes of vanadium contents in the serum at 42 days Data are the means \pm standard deviation $(\mathrm{n}=5) * p<0.05$, compared with the control group ** $p<0.01$, compared with the control group.

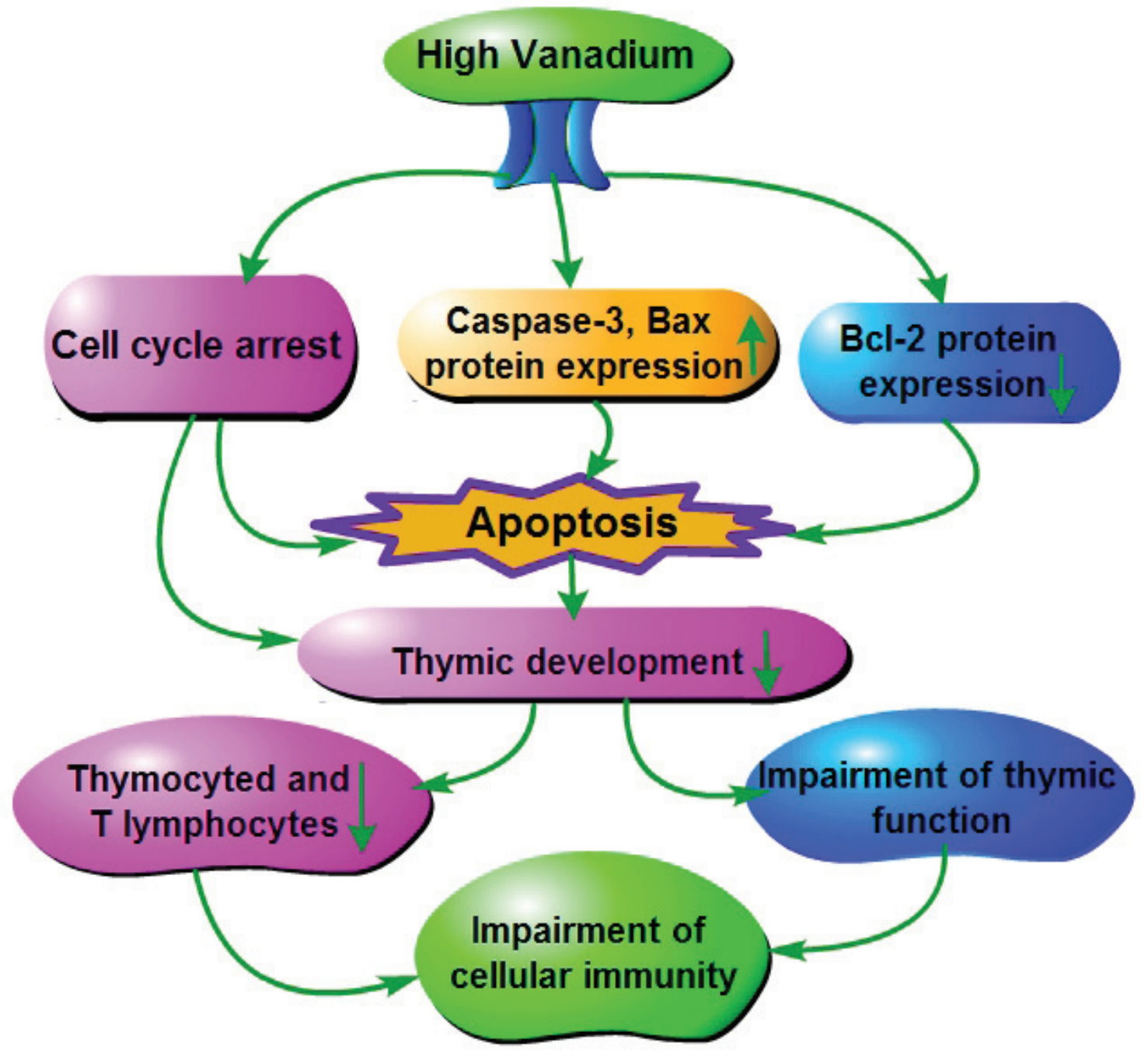

Figure 18: The toxic effect mechanism of vanadium on thymic development Vanadium promotes cell-cycle arrest and caspase-3 and Bax protein expression, and inhibits Bcl-2 protein expression. Cell-cycle arrest, Bax and caspase-3 protein expression upregulation, and Bcl-2 protein expression down-regulation cause apoptosis. Cell-cycle arrest, apoptosis inhibit thymic development, which finally results in impairment of cellular immunity. 
$\mathrm{mg} / \mathrm{kg}$ groups than those of the control group from 14 to 42 days of age. The results were shown in Figures 12 and 13.

Caspase-3 protein expression Changes of the caspase- 3 protein expression levels were consistent with changes of the Bax protein expression levels, as shown in Figures 14 and 15.

\section{Changes of vanadium contents in the thymus and serum}

The results in Figures 16 and 17 showed that the vanadium contents in the thymus and serum were increased as dietary vanadium increased. Vanadium contents were found to be significantly higher $(P<0.01$ or $P<0.05)$ in the $30 \mathrm{mg} / \mathrm{kg}, 45 \mathrm{mg} / \mathrm{kg}$ and $60 \mathrm{mg} / \mathrm{kg}$ groups than those in the control group.

\section{DISCUSSION}

The aim of this study was to define the toxic effect of dietary vanadium on thymic development. Indeed, we found considerable evidence that dietary high vanadium ( in the range of $30 \mathrm{mg} / \mathrm{kg}$ to $60 \mathrm{mg} / \mathrm{kg}$ ) had adverse effects on thymic development: reduced relative weight (Figure 1), arrested cell-cycle (Figures 2-6) and increased apoptosis (Figures 7-9). Relative weight has been considered as a satisfactory measure of nutritive value, which can also represent the development state of organs [76]. In the present study, the results showed that the thymic development was obviously inhibited in the three high vanadium groups, which was consistent with the cell cycle arrest.

In order to reveal the mechanism of thymic development suppression caused by dietary high vanadium, we used flow cytometry to analyze the cell cycle of thymocytes. Cell cycle includes S (DNA replication), $M$ (nuclear division and cell division), $\mathrm{G}_{1}$ (the cell-cycle gap phase between $\mathrm{M}$ phase and $\mathrm{S}$ phase), $\mathrm{G}_{2}$ (the cell-cycle gap phase between $\mathrm{S}$ phase and $\mathrm{M}$ phase) phases, which is central to maintain homeostasis in the multicellular organisms [77]. The results showed that high vanadium caused arrest at the $\mathrm{G}_{0} / \mathrm{G}_{1}$ phases, which inhibited damaged cells to stop DNA replication at $\mathrm{G}_{1}$ phase, and ultimately resulted in the thymocyte apoptosis when damaged cells can't be repaired. This observation was supported by the findings that high vanadium caused decreased numbers of thymocytes in the S phase and diminished PI of thymocytes (Figures 5 and 6), and increased percentage of apoptotic thymocytes (Figures 7-9). It is clear that the cell cycle arrest and apoptosis of thymocytes can be the main mechanism of thymic development suppression caused by dietary high vanadium.

Apoptosis is the programmed cell death in eukaryotes, which is essential for development and tissue homeostasis by providing a protective mechanism to clean out aged or damaged cells [78, 79]. Apoptosis is tightly controlled by changes, interactions and posttranslational modifications (including proteolytic cleavage and phosphorylation) of proteins [80]. In the present study, the results of FCM and TUNEL assays showed that dietary high vanadium increased the percentage of splenocyte apoptosis, which was consistent with the increased Bax and caspase- 3 protein expression levels and decreased Bcl-2 protein expression levels in the thymus due to the close relationship between apoptosis and apoptotic protein expression levels. It is well known that increase in pro-apoptotic protein expression or decrease in antiapoptotic protein expression can push cells down the apoptotic pathway. The Bcl-2 family consists of the antiapoptotic proteins (Bcl-2-like proteins such as Bcl-2 and $\mathrm{Bcl}-\mathrm{X}_{\mathrm{L}}$ ), and the pro-apoptotic proteins (such as bax-like and the BH3-only proteins) [81]. Activation of the proapoptotic proteins induces cytochrome $\mathrm{C}$ release from mitochondria into the cytoplasm [82-85]. Nevertheless, Bcl-2-like proteins can prevent Bax-induced cell death by blocking cytochrome $\mathrm{C}$ release [85]. As a pro-apoptotic protein, caspase- 3 is activated in the apoptotic cell both by extrinsic (death ligand) and intrinsic (mitochondrial) pathways [86, 87], and executes the apoptotic process [88] . Also, the increased apoptotic thymocytes are closely correlated to the cell cycle arrest caused by dietary high vanadium.

The thymus is essential to the differentiation and development of $\mathrm{T}$ cells. $\mathrm{T}$ cells develop until mature in the thymus, and then migrate to the peripheral blood and lymphatic system. The thymic development suppression caused by dietary high vanadium can reduce the thymocyte numbers and inhibit the thymic hormone synthesis, implying that mature $\mathrm{T}$ lymphocytes in the thymus, and $\mathrm{T}$ lymphocytes in the peripheral blood decrease in number [55]. Simultaneously, dietary high vanadium has been reported to reduce $\mathrm{T}$ lymphocyte numbers in the lymphatic organ or tissue, such as spleen, cecal tonsil and ileum $[57,60,64]$. T lymphocytes take part in cellular immunity. Thus, the cellular immune function is finally impaired due to the decreased T-lymphocyte numbers and reduced $\mathrm{T}$ lymphocyte activities in the peripheral blood and lymphatic organ or tissue caused by dietary high vanadium.

Based on the results of our study and the abovementioned discussion, the toxic effect mechanism of dietary high vanadium on thymic development is summarized in Figure 18.

The decreased relative weight, cell cycle arrest and increased apoptosis percentages are consistent with vanadium accumulation in the thymus (Figures 16 and 17), indicating that the vanadium accumulation is main or/ and direct reason of the thymic development suppression.

Concurrently, dietary $5 \mathrm{mg} / \mathrm{kg}$ vanadium promotes 
the thymic development by increasing relative weight, decreasing $\mathrm{G}_{0} / \mathrm{G}_{1}$ phase, increasing $\mathrm{S}$ phase and PI, and reducing percentages of apoptotic thymocytes when compared to the control group and high vanadium groups.

In conclusion, dietary high vanadium (in the range of $30 \mathrm{mg} / \mathrm{kg}$ to $60 \mathrm{mg} / \mathrm{kg}$ ) causes the toxic effect on thymic development by decreasing relative weight, arresting cell cycle, increasing apoptosis percentage. The thymic development suppression caused by dietary high vanadium further leads to inhibitive effects on $\mathrm{T}$ lymphocyte maturity and activity, and cellular immune function in the chicken. This study provides a new evidence for further understanding the vanadium immunotoxicity. In contrast, dietary $5 \mathrm{mg} / \mathrm{kg}$ vanadium promotes the thymic development by increasing relative weight, decreasing $\mathrm{G}_{0} / \mathrm{G}_{1}$ phase, increasing $\mathrm{S}$ phase and PI, and reducing percentages of apoptotic thymocytes when compared to the control group and high vanadium groups.

\section{MATERIALS AND METHODS}

\section{Chickens and diets}

Four hundred and twenty one-day-old healthy broilers were divided into six groups. There were 70 broilers in each group. The broilers were housed in cages with electrically heated units and were provided with water as well as the under-mentioned control or experimental diets ad libitum for 42 days.

A corn-soybean basal diet formulated by the National Research Council [89] was the control diet (vanadium $0.073 \mathrm{mg} / \mathrm{kg}$ ). Ammonium metavanadate $\left(\mathrm{NH}_{4} \mathrm{VO}_{3}\right)$ was mixed into the corn-soybean basal diet to produce experimental diets with $5 \mathrm{mg} / \mathrm{kg}, 15 \mathrm{mg} / \mathrm{kg}, 30$ $\mathrm{mg} / \mathrm{kg}, 45 \mathrm{mg} / \mathrm{kg}$ and $60 \mathrm{mg} / \mathrm{kg}$ of vanadium, respectively.

Our experiments involving the use of broilers and all experimental procedures involving animals were approved by Animal Care and Use Committee, Sichuan Agricultural University.

\section{Clinical signs and the relative weight of thymus}

Clinical signs were observed and recorded every day. At 7, 14, 21, 28, 35 and 42 days of age during the experiment, five broilers in each group were humanely euthanized after they were weighed. Thymus was taken from each broiler and weighed after dissecting connective tissue around the organ. Related weight of thymus was calculated by the following formula:

Related weight $=$ organ weight $(\mathrm{g}) /$ body weight $(\mathrm{kg})$

\section{Determination of cell cycle stages by flow cytometry}

At 14, 28, and 42 days of age, five broilers in each group were selected for determination of the cell-cycle stages in the thymus by flow cytometry, as described by Cui et al. [58].

Thymuses were immediately removed and macerated by grinding to form a cell suspension that was filtered through 300-mesh nylon screen. The cells were washed twice with cold phosphate buffer solution ( $\mathrm{pH}$ 7.27.4 ), and were then suspended in $1 \times$ binding buffer (Cat. No. 51-66121E) at a concentration of $1 \times 10^{6}$ cells $/ \mathrm{mL}$. Five hundred microliters of the solution was transferred to a 5-mL culture tube and centrifuged (500-1,000 rpm). After removing the supernatant, $5 \mu \mathrm{L} 0.25 \%$ Triton X-100 and $5 \mu \mathrm{L}$ PI (Cat. No. 51-66211E) were added. The cells were gently vortexed and incubated for $30 \mathrm{~min}$ at $25^{\circ} \mathrm{C}$ in the dark. Finally, $500 \mu \mathrm{L}$ PBS was added to each tube, and the contents were analyzed by flow cytometry (BD FACSCalibur) within 45 min.

\section{Determination of apoptosis in the thymus}

Flow cytometry method At 14, 28, and 42 days of age, five chickens in each group were humanely euthanized. Thymuses were taken for the determination of apoptotic thymocytes by flow cytometry, as described by Peng et al. [90].

The cell suspension was prepared as described in the method of cell of cycle. One hundred microliters of the solution was transferred to a 5-ml culture tube, and then $5 \mu \mathrm{l}$ of Annexin V-FITC (Cat. No: 51-65874X) and $5 \mu \mathrm{l}$ of PI (Cat. No: 51-66211E) were added. The cells were gently vortexed and incubated for $15 \mathrm{~min}$ at room temperature $\left(25^{\circ} \mathrm{C}\right)$ in the dark. Four hundred microliters of $1 \times$ binding buffer was added to each tube and analyzed by flow cytometry within $1 \mathrm{~h}$.

TUNEL assay Five broilers in each group were humanely euthanized at 42 days of age. Thymuses were taken and fixed in 10\% neutral buffered formalin after postmortem examination, and then processed and trimmed, embedded in paraffin.

TUNEL assay was carried out according to the manual of In Situ Cell Death Detection Kit (Cat: 11684817980, Roche, Germany). Briefly, tissue sections ( $5 \mu \mathrm{m}$ thick) were rehydrated in a series of xylene and ethanol solutions and then rinsed in $\mathrm{ddH}_{2} \mathrm{O}$, digested with proteinase $\mathrm{K} 50 \mu \mathrm{l}$ (Tris $\cdot \mathrm{HCl} \mathrm{pH7.8} \mathrm{diluted)} \mathrm{for} 15$ min, then incubated with $3 \% \mathrm{H}_{2} \mathrm{O}_{2}$ in methanol for 15 $\mathrm{min}$ at RT (room temperature) to inactivate endogenous peroxidase. Subsequently, sections were transferred to a reaction mixture containing biotin-dUTP terminal deoxynucleotidyl and incubated in a humid chamber for 1 $\mathrm{h}$ at $37^{\circ} \mathrm{C}$, followed by washing in phosphate buffer saline 
(PBS, pH 7.2-7.4). Sections were incubated in ConverterPOD (HRP) for $30 \mathrm{~min}$ at $37^{\circ} \mathrm{C}$. Reaction product was visualized with DAB kit (AR1022, Boster, Wuhan, China). After a final washes in $\mathrm{dd}_{2} \mathrm{O}$, slices were lightly counterstained with hematoxylin, dehydrated in ethanol, cleared in xylene and mounted.

\section{Determination of Bcl-2, Bax, and caspase-3 protein expression in the thymus by immunohistochemistry}

At 14, 28 and 42 days of age, five broilers in each group were humanely euthanized. Thymuses were taken for the detection of Bax, Bcl-2 and caspase- 3 protein expression by the immunohistochemical methods (SABC) and stained with DAB as described by Wang et al [91]. Anti-Bax (BA0315), anti-Bcl-2 (BA0412) and anticaspase-3 (BA0588), and DAB were purchased from Wuhan Boster Biological Technology Co., Ltd., China.

Images from five slices per thymus were taken 200 $\mu \mathrm{m}$ apart. Five visions per slice were randomly chosen for assessment of positive cells using image analysis software (JID801D). The average grayscale of the positive cells was automatically calculated. Immunoreactive intensity was expressed by average grayscale. Values $<160$ was considered high, 160-170 medium and 170-180 low.

\section{Determination of vanadium contents in the thymus and serum}

Vanadium contents in the thymus and serum were determined by inductively coupled plasma optical emission spectrometry (ICP-OES).

Thymus At 42 days of age, five thymus in each group were taken and torrefied. $0.1 \mathrm{~g}$ torrefied sample from each thymus was treated with $2 \mathrm{ml} \mathrm{HNO}_{3}$ and $1 \mathrm{ml}$ $\mathrm{H}_{2} \mathrm{O}_{2}$ and dissolved using the automatic microwave-heated digestion system. The volume of the digestive production was increased to $25 \mathrm{ml}$ by the addition of deionized water, which resulted in a clear, colorless solution. At the same time, the blanks of the reagents were created via the same procedure without thymic sample. Then, the treated thymic samples were analyzed by ICP-OES $(5,300 \mathrm{~V}, \mathrm{PE}$ Ltd, USA).

Serum The serum of five chickens in each group was taken at 42 days of age. $1 \mathrm{~mL}$ serum from each chicken was treated with $2 \mathrm{ml} \mathrm{HNO}_{3}$ and $1 \mathrm{ml} \mathrm{H}_{2} \mathrm{O}_{2}$ and dissolved using the automatic microwave-heated digestion system. The volume of the digestive production was increased to $25 \mathrm{ml}$ by the addition of deionized water, which resulted in a clear, colorless solution. At the same time, the blanks of the reagents were created via the same procedure without serum sample. Then, the treated serum samples were analyzed by ICP-OES (5,300 V, PE Ltd, USA).

\section{Statistical analysis}

The significance of difference between the control groups and the vanadium-treated groups was analyzed by the use of variance analysis, and the results are presented as means \pm standard deviation $(\mathrm{X} \pm \mathrm{SD})$. The analysis was performed with the one-way analysis of variance (ANOVA) test of SPSS 16.0 for windows. A value of $P<$ 0.05 was considered significant.

\section{ACKNOWLEDGMENTS}

The study was supported by the program for Changjiang scholars and innovative research team in university (IRT0848) and the Shuangzhi project of Sichuan Agricultural University (03570327; 03571198).

\section{CONFLICTS OF INTEREST}

The authors declare no conflict of interest.

\section{REFERENCES}

1. French RJ and Jones PJ. Role of vanadium in nutrition: metabolism, essentiality and dietary considerations. Life Sci. 1993; 52:339-346.

2. Nielsen FH. New essential trace elements for the life sciences. Biol Trace Elem Res. 1990; 26:599-611.

3. Richie D. The effects of toxicity induced by feeding selected elements. Agri-Practice (USA). 1985.

4. Imura H, Shimada A, Naota M, Morita T, Togawa M, Hasegawa $\mathrm{T}$ and Seko Y. Vanadium toxicity in mice: possible impairment of lipid metabolism and mucosal epithelial cell necrosis in the small intestine. Toxicol Pathol. 2013; 41:842-856.

5. Hopkins Jr L and Mohr H. (1974). Proceedings: Vanadium as an essential nutrient. Fed Proc, pp. 1773.

6. Huang C, Ding M, Li J, Leonard SS, Rojanasakul Y, Castranova V, Vallyathan V, Ju G and Shi X. Vanadiuminduced nuclear factor of activated $\mathrm{T}$ cells activation through hydrogen peroxide. J Biol Chem. 2001; 276:2239722403.

7. Ortiz-Bernad I, Anderson RT, Vrionis HA and Lovley DR. Vanadium respiration by Geobacter metallireducens: novel strategy for in situ removal of vanadium from groundwater. Appl Environ Microb. 2004; 70:3091-3095.

8. Byczkowski JZ, Wan B and Kulkarni AP. Vanadiummediated lipid peroxidation in microsomes from human term placenta. B Environ Contam Tox. 1988; 41:696-703.

9. Jelikić-Stankov M, Uskoković-Marković S, HolclajtnerAntunović I, Todorović M and Djurdjević P. Compounds of Mo, $\mathrm{V}$ and $\mathrm{W}$ in biochemistry and their biomedical activity. J Trace Elem Med Bio. 2007; 21:8-16.

10. Yuen Y, Pederson RA, Dai S, Orvig C and McNeill 
JH. Effects of low and high dose administration of bis (maltolato) oxovanadium (IV) on fa/fa Zucker rats. Can J Physiol Pharm. 1996; 74:1001-1015.

11. Sekar N, Li J and Shechter Y. Vanadium salts as insulin substitutes: mechanisms of action, a scientific and therapeutic tool in diabetes mellitus research. Crit Rev Biochem Mol 1996; 31:339-359.

12. Dubyak GR and Kleinzeller A. The insulin-mimetic effects of vanadate in isolated rat adipocytes. J Biol Chem. 1980; 255:5306-5312.

13. Crans DC, Smee JJ, Gaidamauskas E and Yang L. The chemistry and biochemistry of vanadium and the biological activities exerted by vanadium compounds. Chem Rev. 2004; 104:849-902.

14. Domingo JL. Vanadium and tungsten derivatives as antidiabetic agents. Biol Trace Elem Res. 2002; 88:97-112.

15. Bishayee A and Chatterjee M. Time course effects of vanadium supplement on cytosolic reduced glutathione level and glutathione S-transferase activity. Biol Trace Elem Res. 1995; 48:275-285.

16. Madsen K, Ariano D and Fedorak R. Vanadate treatment rapidly improves glucose transport and activates 6-phosphofructo-1-kinase in diabetic rat intestine. Diabetologia. 1995; 38:403-412.

17. Yilmaz-Ozden T, Kurt-Sirin O, Tunali S, Akev N, Can A and Yanardag R. Ameliorative effect of vanadium on oxidative stress in stomach tissue of diabetic rats. Bosn J Basic Med Sci. 2014; 14:105.

18. Hosseini JP, Shaki F and M Ghazi Khansari M. Toxicity of Vanadium $(\mathrm{V}+5)$ on isolated rat liver mitochondria. Res Pharm Sci. 2012; 7:S184.

19. Korbecki J, Baranowska-Bosiacka I, Gutowska I and Chlubek D. Vanadium Compounds as Pro-Inflammatory Agents: Effects on Cyclooxygenases. Int J Mol Sci. 2015; 16:12648-12668.

20. Sun L, Shi DJ, Gao XC, Mi SY, Yu Y and Han Q. The protective effect of vanadium against diabetic cataracts in diabetic rat model. Biol Trace Elem Res. 2014; 158:219223.

21. Bishayee A, Waghray A, Patel MA and Chatterjee M. Vanadium in the detection, prevention and treatment of cancer: the in vivo evidence. Cancer Lett. 2010; 294:1-12.

22. Suwalsky M, Fierro P, Villena F, Gallardo MJ, JemiolaRzeminska M, Strzalka K, Gul-Hinc S, Ronowska A, Zysk $\mathrm{M}$ and Szutowicz A. Effects of sodium metavanadate on in vitro neuroblastoma and red blood cells. Arch Biochem Biophys. 2013; 535:248-256.

23. Wu Y, Ma Y, Xu Z, Wang D, Zhao B, Pan H, Wang J, Xu D, Zhao X, Pan S, Liu L, Dai W and Jiang H. Sodium orthovanadate inhibits growth of human hepatocellular carcinoma cells in vitro and in an orthotopic model in vivo. Cancer Lett. 2014; 351:108-116.

24. Mishra M, Mathur R and Gautam R. Therapeutic application of some chelating agents against intoxication of Vanadium compounds in the reproductive organs of male rats. Glob Adv Res J Microbiol. 2013; 2:017-021.

25. Ousterhout LE and Berg LR. Effects of diet composition on vanadium toxicity in laying hens. Poultry Sci. 1981; 60:1152-1159.

26. Liochev SI and Fridovich I. Vanadate-stimulated oxidation of $\mathrm{NAD}(\mathrm{P}) \mathrm{H}$ in the presence of biological membranes and other sources of O2. Arch Biochem Biophys. 1990; 279:1-7.

27. Paternain JL, Domingo JL, Gomez M, Ortega A and Corbella J. Developmental toxicity of vanadium in mice after oral administration. J Appl Toxicol. 1990; 10:181-186.

28. Franke KW and Moxon AL. The toxicity of orally ingested arsenic, selenium, tellurium, vanadium and molybdenum. J Pharmacol Exp Ther. 1937; 61:89-102.

29. Cortizo AMa, Bruzzone L, Molinuevo S and Etcheverry SB. A possible role of oxidative stress in the vanadium-induced cytotoxicity in the MC3T3E1 osteoblast and UMR106 osteosarcoma cell lines. Toxicology. 2000; 147:89-99.

30. Goldblatt M. Vanadium pentoxide dust: A clinical and experimental investigation on its effect after inhalation. $\mathrm{Br}$ J Ind Med. 1950; 7:195.

31. Stokinger HE. Organic, beryllium and vanadium dusts; a review. AMA Arch Ind Health. 1955; 12:675-677.

32. Doig A. Vanadium: Toxicology and biological significance. Br J Ind Med. 1965; 22:163.

33. Ray RS, Rana B, Swami B, Venu V and Chatterjee M. Vanadium mediated apoptosis and cell cycle arrest in MCF7 cell line. Chem Biol Interact. 2006; 163:239-247.

34. Roy S, Majumdar S, Singh AK, Ghosh B, Ghosh N, Manna S, Chakraborty T and Mallick S. Synthesis, Characterization, Antioxidant Status, and Toxicity Study of Vanadium-Rutin Complex in Balb/c Mice. Biol Trace Elem Res. 2015; 166:183-200.

35. Li H, Zhou D, Zhang Q, Feng C, Zheng W, He K and Lan Y. Vanadium exposure-induced neurobehavioral alterations among Chinese workers. Neurotoxicology. 2013; 36:49-54.

36. Hosseini MJ, Shaki F, Ghazi-Khansari M and Pourahmad J. Toxicity of vanadium on isolated rat liver mitochondria: a new mechanistic approach. Metallomics : integrated biometal science. 2013; 5:152-166.

37. Rojas-Lemus M, Altamirano-Lozano M and Fortoul TI. Sex differences in blood genotoxic and cytotoxic effects as a consequence of vanadium inhalation: micronucleus assay evaluation. J Appl Toxicol. 2014; 34:258-264.

38. Kleinsasser N, Dirschedl P, Staudenmaier R, Harreus U and Wallner B. Genotoxic effects of vanadium pentoxide on human peripheral lymphocytes and mucosal cells of the upper aerodigestive tract. Int J Environ Health Res. 2003; 13:373-379.

39. Capella LS, Gefe MR, Silva EF, Affonso-Mitidieri O, Lopes AG, Rumjanek VM and Capella MA. Mechanisms of vanadate-induced cellular toxicity: role of cellular glutathione and NADPH. Arch Biochem Biophys. 2002; 406:65-72. 
40. Leopardi P, Villani P, Cordelli E, Siniscalchi E, Veschetti $\mathrm{E}$ and Crebelli R. Assessment of the in vivo genotoxicity of vanadate: analysis of micronuclei and DNA damage induced in mice by oral exposure. Toxicol Lett. 2005; 158:39-49.

41. Villani P, Cordelli E, Leopardi P, Siniscalchi E, Veschetti E, Fresegna AM and Crebelli R. Evaluation of genotoxicity of oral exposure to tetravalent vanadium in vivo. Toxicol Lett. 2007; 170:11-18.

42. Afeseh Ngwa H, Kanthasamy A, Anantharam V, Song C, Witte T, Houk R and Kanthasamy AG. Vanadium induces dopaminergic neurotoxicity via protein kinase Cdelta dependent oxidative signaling mechanisms: relevance to etiopathogenesis of Parkinson's disease. Toxicol Appl Pharmacol. 2009; 240:273-285.

43. Ścibior A, Gołębiowska D and Niedźwiecka I. Magnesium can protect against vanadium-induced lipid peroxidation in the hepatic tissue. Oxid Med Cell Longev. 2013; 2013.

44. Hosseini M-J, Seyedrazi N, Shahraki J and Pourahmad J. Vanadium induces liver toxicity through reductive activation by glutathione and mitochondrial dysfunction. Adv Biosci Biotechnol. 2012; :1096-1103.

45. Farid HE, Abozid MM and Mahmoud KE. Short term effects of vanadium and nickel intoxication on rats liver antioxidant defence system. Int J Acad Res. 2012; 4.

46. Ngwa HA, Kanthasamy A, Jin H, Anantharam V and Kanthasamy AG. Vanadium exposure induces olfactory dysfunction in an animal model of metal neurotoxicity. Neurotoxicology. 2014; 43:73-81.

47. Visalli G, Bertuccio MP, Picerno I, Spataro P and Di Pietro A. Mitochondrial dysfunction by pro-oxidant vanadium: ex vivo assessment of individual susceptibility. Environ Toxicol Pharmacol. 2015; 39:93-101.

48. Hosseini M-J, Pourahmad J, Shaki F and Ghazi-Khansari M. Vanadium induces oxidative stress in isolated rat liver mitochondria. Toxicol Lett. 2012; 211:S167.

49. Rodríguez-Mercado JJ, Mateos-Nava RA and AltamiranoLozano MA. DNA damage induction in human cells exposed to vanadium oxides in vitro. Toxicol Vitro. 2011; 25:1996-2002.

50. Gonzalez-Villalva A, Pinon-Zarate G, De la Pena Diaz A, Flores-Garcia M, Bizarro-Nevares P, Rendon-Huerta EP, Colin-Barenque L and Fortoul TI. The effect of vanadium on platelet function. Environ Toxicol Pharmacol. 2011; 32:447-456.

51. Kurt O, Ozden TY, Ozsoy N, Tunali S, Can A, Akev N and Yanardag R. Influence of vanadium supplementation on oxidative stress factors in the muscle of STZ-diabetic rats. Biometals : an international journal on the role of metal ions in biology, biochemistry, and medicine. 2011; 24:943-949.

52. Cuesta S, Frances D and Garcia GB. ROS formation and antioxidant status in brain areas of rats exposed to sodium metavanadate. Neurotoxicol Teratol. 2011; 33:297-302.

53. Ghosh SK, Saha R and Saha B. Toxicity of inorganic vanadium compounds. Res Chem Intermed. 2014:1-25.

54. Dinoeva S. Immuno-morphological evaluation of the effect of trace elements on experimental atherosclerosis. Eksp Med Morfol. 1982; 21:130-136.

55. Cui W, Cui HM, Peng X, Zuo Z, Liu X and Wu B. Effect of vanadium on the subset and proliferation of peripheral blood T cells, and serum interleukin-2 content in broilers. Biol Trace Elem Res. 2011; 141:192-199.

56. Cui W, Cui H, Peng X, Fang J, Zuo Z, Liu X and Wu B. Changes of relative weight and cell cycle, and lesions of bursa of Fabricius induced by dietary excess vanadium in broilers. Biol Trace Elem Res. 2011; 143:251-260.

57. Cui W, Cui H, Peng X, Fang J, Zuo Z, Liu X and Wu B. Excess dietary vanadium induces the changes of subsets and proliferation of splenic T cells in broilers. Biol Trace Elem Res. 2011; 143:932-938.

58. Cui W, Cui H, Peng X, Fang J, Zuo Z, Liu X and Wu B. Dietary excess vanadium induces lesions and changes of cell cycle of spleen in broilers. Biol Trace Elem Res. 2011; 143:949-956.

59. Liu X, Cui HM, Peng X, Fang J, Cui W and Wu B. The effect of dietary vanadium on cell cycle and apoptosis of liver in broilers. Biol Trace Elem Res. 2011; 143:15081515.

60. Deng Y, Cui H, Peng X, Fang J, Wang K, Cui W and Liu $\mathrm{X}$. Effect of dietary vanadium on cecal tonsil $\mathrm{T}$ cell subsets and IL-2 contents in broilers. Biol Trace Elem Res. 2011; 144:647-656.

61. Deng Y, Cui H, Peng X, Fang J, Wang K, Cui W and Liu X. Dietary vanadium induces oxidative stress in the intestine of broilers. Biol Trace Elem Res. 2012; 145:52-58.

62. Liu J, Cui H, Liu X, Peng X, Deng J, Zuo Z, Cui W, Deng $\mathrm{Y}$ and Wang K. Dietary high vanadium causes oxidative damage-induced renal and hepatic toxicity in broilers. Biol Trace Elem Res. 2012; 145:189-200.

63. Cui W, Cui H, Peng X, Fang J, Zuo Z, Liu X and Wu B. Dietary vanadium induces lymphocyte apoptosis in the bursa of Fabricius of broilers. Biol Trace Elem Res. 2012; 146:59-67.

64. Wang K, Cui H, Deng Y, Peng X, Fang J, Zuo Z and Cui $W$. Effect of dietary vanadium on the ileac $T$ cells and contents of cytokines in broilers. Biol Trace Elem Res. 2012; 147:113-119

65. Deng Y, Cui H, Peng X, Fang J, Zuo Z, Wang K, Cui W and $\mathrm{Wu} \mathrm{B}$. Changes of IgA+ cells and cytokines in the cecal tonsil of broilers fed on diets supplemented with vanadium. Biol Trace Elem Res. 2012; 147:149-155.

66. Wang K, Cui H, Deng Y, Peng X, Zuo Z, Fang J, Deng J, Cui $\mathrm{W}$ and $\mathrm{Wu} \mathrm{B}$. Effect of dietary vanadium on intestinal microbiota in broiler. Biol Trace Elem Res. 2012; 149:212218.

67. Cui H. Dietary vanadium induces decrease in antioxidant enzyme activities and oxidative stress in the spleens of broilers. Med Chem. 2012. 
68. Deng Y, Cui H, Peng X, Fang J, Zuo Z, Wang K, Cui W and $\mathrm{Wu}$ B. The relevance of cytokines for mucosal immunity induced by dietary vanadium in the intestine of broilers. Med Chem. 2012; 2:114.

69. Wei C, Hengmin C, Xi P, Jing F, Xiaodong L and Bangyuan W. Effect of vanadium on splenocyte apoptosis in broilers. Med Chem. 2012; 2:057-060.

70. Cui W, Cui H, Peng X, Fang J, Zuo Z, Liu X and Wu B. Effect of Vanadium on TLR4 and TLR7 mRNA Expression in the Lymphoid Organs of Broilers. Med Chem. 2012; 2:103-106.

71. Xiaodong L, Hengmin C, Xi P, Jing F, Wei C and Bangyuan W. Suppression of renal cell proliferation, induction of apoptosis and cell cycle arrest: Cytotoxicity of vanadium in broilers. Health (N Y). 2012; 2012.

72. Kangping W, Hengmin C, Xi P, Zhicai Z, Jing F, Junliang D, Yuanxin D, Wei C and Bangyuan W. Effect of dietary vanadium on small intestinal morphology in broilers. Health (N Y). 2012; 2012.

73. Elfant $M$ and Keen CL. Sodium vanadate toxicity in adult and developing rats. Biol Trace Elem Res. 1987; 14:193208.

74. Pearse G. Normal structure, function and histology of the thymus. Toxicol Pathol. 2006; 34:504-514.

75. Chen K, Shu G, Peng X, Fang J, Cui H, Chen J, Wang F, Chen Z, Zuo Z and Deng J. Protective role of sodium selenite on histopathological lesions, decreased T-cell subsets and increased apoptosis of thymus in broilers intoxicated with aflatoxin B 1. Food Chem Toxicol. 2013; 59:446-454.

76. Chen T, Cui H, Cui Y, Bai C, Gong T and Peng X. Cellcycle blockage associated with increased apoptotic cells in the thymus of chickens fed on diets high in fluorine. Hum Exp Toxicol. 2011; 30:685-692.

77. Hartwell LH and Kastan MB. Cell cycle control and cancer. Science. 1994; 266:1821-1828.

78. Wei MC, Zong WX, Cheng EH, Lindsten T, Panoutsakopoulou V, Ross AJ, Roth KA, MacGregor GR, Thompson CB and Korsmeyer SJ. Proapoptotic BAX and BAK: a requisite gateway to mitochondrial dysfunction and death. Science. 2001; 292:727-730.

79. Bratton SB, MacFarlane M, Cain K and Cohen GM. Protein complexes activate distinct caspase cascades in death receptor and stress-induced apoptosis. Exp Cell Res. 2000; 256:27-33.

80. Martin LJ, Liu Z, Pipino J, Chestnut B and Landek MA. Molecular regulation of DNA damage-induced apoptosis in neurons of cerebral cortex. Cereb Cortex. 2009; 19:12731293.

81. Desagher S, Osen-Sand A, Nichols A, Eskes R, Montessuit S, Lauper S, Maundrell K, Antonsson B and Martinou J-C. Bid-induced conformational change of Bax is responsible for mitochondrial cytochrome c release during apoptosis. J Cell Biol. 1999; 144:891-901.
82. Saito M, Korsmeyer SJ and Schlesinger PH. BAXdependent transport of cytochrome $\mathrm{c}$ reconstituted in pure liposomes. Nat Cell Biol. 2000; 2:553-555.

83. Wei MC, Lindsten T, Mootha VK, Weiler S, Gross A, Ashiya M, Thompson $\mathrm{CB}$ and Korsmeyer SJ. tBID, a membrane-targeted death ligand, oligomerizes BAK to release cytochrome c. Genes Dev 2000; 14:2060-2071.

84. Szegezdi E, MacDonald DC, Chonghaile TN, Gupta S and Samali A. Bcl-2 family on guard at the ER. Am J PhysiolCell Ph. 2009; 296:C941-C953.

85. Jiang $\mathrm{X}$ and Wang $\mathrm{X}$. Cytochrome $\mathrm{C}$-mediated apoptosis. Annu Rev Biochem. 2004; 73:87-106.

86. Salvesen GS. Caspases: opening the boxes and interpreting the arrows. Cell Death Differ. 2002; 9:3-5.

87. Ghavami S, Hashemi M, Ande SR, Yeganeh B, Xiao W, Eshraghi M, Bus CJ, Kadkhoda K, Wiechec E and Halayko AJ. Apoptosis and cancer: mutations within caspase genes. J Med Genet. 2009; 46:497-510.

88. Chen TA, Yang F, Cole GM and Chan SO. Inhibition of caspase-3-like activity reduces glutamate induced cell death in adult rat retina. Brain Res. 2001; 904:177-188.

89. NRC. (1994). Nutrient Requirements of Poultry, 9th ed.: National Academy Press: Washington, DC, USA).

90. Peng X, Cui Y, Cui W, Deng J and Cui H. The decrease of relative weight, lesions, and apoptosis of bursa of fabricius induced by excess dietary selenium in chickens. Biol Trace Elem Res. 2009; 131:33-42.

91. Wang J-M, Xiao B-L, Zheng J-W, Chen H-B and Zou S-Q. Effect of targeted magnetic nanoparticles containing 5-FU on expression of bcl-2, bax and caspase 3 in nude mice with transplanted human liver cancer. World J Gastroenterol. 2007; 13:3171-3175. 